\title{
The Effect of Labor Market Polarization on the College Students' Employment
}

\author{
Sungyup Chung*
}

The views expressed herein are those of the authors and do not necessarily reflect the official views of the Bank of Korea. When reporting or citing this paper, the authors' names should always be explicitly stated.

* Economist, Research Department (former Economist, Economic Research Institute), The Bank of Korea, Tel: +82-2-759-4291, E-mail: sychung@bok.or.kr.

The author is grateful to Hyun Hak Kim, Yunmi Nam, Seryoung Park, and other anonymous referees for their valuable comments on this paper. 


\section{Contents}

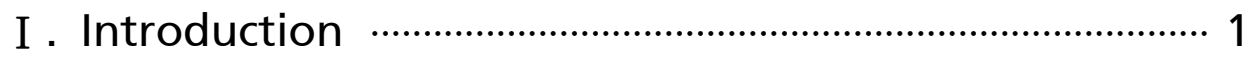

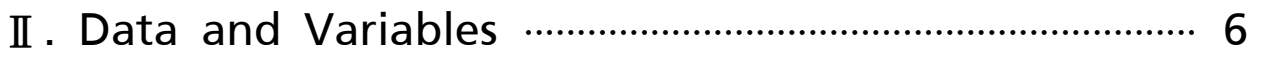

III. Estimation Results …......................................................... 12

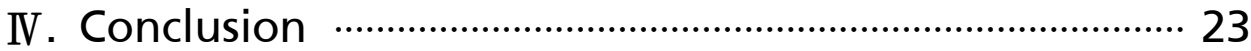

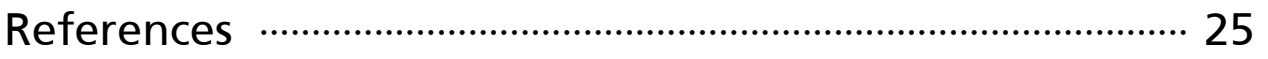

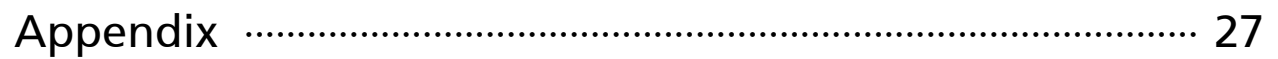




\section{The Effect of Labor Market Polarization on the College Students' Employment}

This paper aims to assess the effect of the labor market environment on various aspects of college students' job market related behaviors. In some cases, college students hide or evade their unemployment status by extending school registration or transferring to another school. By estimating the effect of the macroeconomic variables on college students' labor market related outcomes, it is found that labor market polarization has a significant effect on both the nominal unemployment and the hidden actions of college students. It implies that the labor market structure is a key element in understanding youth employment, and the youth labor policy should focus more on micro and institutional level of labor market reform.

Keywords: Labor market, Youth unemployment, Cox proportional hazard model

JEL Classification: C24, J31, J40, J81 


\section{I . Introduction}

Contrary to the recovering trend observed in the overall labor market indicators, the youth labor market is yet to exhibit any sign of recovery after the Global Financial Crisis. For example, the youth unemployment rate in 2015 scored $9.2 \%$ which is the highest since year 2000, whereas the overall unemployment rate is decent $3.6 \%$.

This implies that there can be some obstacles that hinder the youth labor market from getting better, and one of the candidates of the obstacles is the labor market structure. If the labor market is fragmented into primary market with relatively good compensation and secondary market with relatively bad compensation schedule, youth labor might suffering from longer job searching period in an attempt to get a position in the primary market.

More than $70 \%^{1)}$ of high school students enter college after graduation in Korea. Including repeaters, the college entrance rate should be over $80 \%$, implying that the analysis of college students' labor market outcomes is essential to understand youth unemployment.

This paper aims to see how the labor market environment, namely the polarization of the labor market will affect college students' behaviors related to their careers. Most of the previous studies on youth workforce have dealt with the unemployment variable or the probability of getting unemployed after graduation (unemployment duration), or concentrated on individual characteristics that determine unemployment. This paper, however, tries to identify the effect of macroeconomic factors as well as individual factors on various aspects of college students' job market related outcomes.

Since the unemployment experience in the early career stage will look bad to potential employers, students try to hide or evade their jobless status by extending school registration or transferring to another school. By looking at their job market related activities during and after college years, hidden unemployment of college students can be understood, minimizing any left-outs.

1) $70.8 \%$ for year 2015 . 
In this sense, this paper tries to cover most of the job market related outcomes from unemployment to additional education after graduation.

Also, by looking at the macroeconomic environment surrounding the labor market, such as the GDP growth rate and the labor market structure, we can investigate what determines the performances of the youth labor market and draw implications for the labor market policy. This paper aims to contribute to the literature by assessing college students' job market related behaviors in a more integrated way, and expand our knowledge to how the labor market structure such as labor market polarization might affect youth employment.

Unlike workers in other age groups, there are some characteristics specific to young workers or college graduates. For example, the unemployment rate of young workers is higher than that of any other age groups. As of 2015, the unemployment rate of workers in their $20 \mathrm{~s}$ is about $9.1 \%$, which is about $6.5 \% \mathrm{p}$ higher than those of other worker groups, implying that firms have superior bargaining power over labor compared to other age cohorts (Figure 1).2) Another characteristic of the labor market related activities of college students is that some of them can avoid or conceal their unemployment status on their resume by enrolling extra semesters and postponing graduation. As Figure 2 suggests, except for the obligatory military service, preparing for the job market ${ }^{3)}$ is the number one cause of a leave of absence, implying that the actual unemployment rate of college graduates will be higher than the official figure. These differences might be originated from the imperfect substitution between workers of different age groups ${ }^{4}$, and consequentially, the labor market that college graduates confront should be different from the labor markets for other age groups. More specifically, as starters in the job market, college students in Korea are sensitive to their first job while the market situation is harsh for

2) Similarly, according to college graduates' career path survey data, about $11 \%$ of college graduates are neither employed nor registered to any other school for the period of 2003 to 2013.

3) Examples include short-term internship, language training, etc.

4) Studies regarding imperfect substitutions between workers of different age groups can be found in Dougherty (1972), Ferguson (1986) and many other literatures. Most of the empirical analyses studying the substitutability of the workers of different age groups (ex. Hamermesh and Grant (1979), Merrilees (1982) and Lewis (1985)) find that the substitution between workers are imperfect, creating separate markets specific to age cohorts. 
Figure 1: Unemployment Rate Figure 2: Causes of Leave of Absence

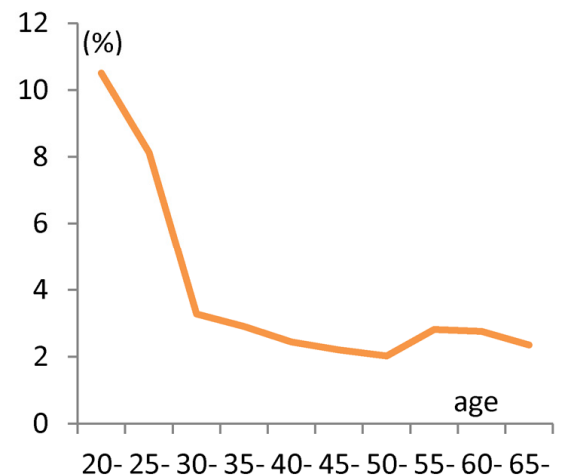

Source: Korean Statistical Information Service (2015)

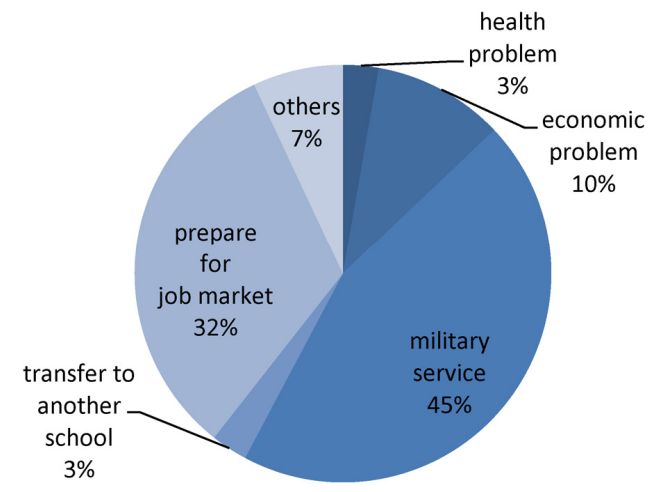

Source: College Graduates' Career Path Survey (2004-2013)

young workers. Thus, good preparation is essential for their successful job market related outcomes.

In this sense, in order to assess the job market performances of college graduates, job market related outcomes such as the length of college enrollment and probability of entering other schools after graduation should be also considered. Meanwhile most of the previous studies on the employment of college graduates focus on the unemployment duration and unemployment rate which constitute the nominal value of youth unemployment. When an unfavorable labor market situation hits college students, they can react against the situation in various ways instead of simply becoming unemployed or trying to find a job after graduation. An integrated view is needed in order to understand how young workers respond to the labor market situation.

In selecting the variables representing the labor market situation, GDP growth rate and labor market polarization index (PI herein after) developed by Chung and Jung (2016) are chosen, which is to reflect the cyclical aspects as well as the distributional aspects of the labor market. Many previous studies on the determinants of unemployment also have tried to reflect the cyclical aspects of the labor market such as productivity growth (Jimeno and Rodriguez-Palenzuela, 2002) and unemployment regime (Arulampalam and Stewart, 1995). In this 
paper, it is assumed that GDP growth will capture how favorable the labor market is to potential job seekers since the degree of economic activities should reflect the firms' demand on labor.

Additionally, in an attempt to consider the structural aspect of the labor market, PI is used to grasp how harsh the labor market is to job seekers. More precisely, jobs can be categorized into good jobs in the primary market, bad jobs in the secondary market and other jobs in the intermediary market. PI is simply the portion of the primary and the secondary labor market to the total labor market.5) Thus, the larger value of PI implies less intermediary job openings in the market, implying that if a worker falls into the secondary market, the opportunity for the worker to evolve into a better position will be limited.

In many previous studies on the labor market dualism, it is noted that some job seekers may be willing to wait until they get opportunities in the primary sector. Consequentially, if the labor market is segmented and polarized, then the involuntary or hidden unemployment should rise.6) If young workers look forward to being hired in the primary market, they might refrain from getting a job in the secondary market since working experience in the secondary market can be regarded as a signal of an unproductive worker to potential employers. Thus, even when the economy is good, the job market situation can be bad, especially for young job market candidates. For example, even though the number of job openings is large, if promising jobs are limited or the odds of ending up positioned in the secondary labor market are immense, students might postpone their graduation and seek to accumulate more human capital in order to get into the primary market. In this rationale, PI is used intending to reflect this structural aspect of the labor market.

Other studies also try to find the implications for the effect of institutional variables such as tax wedge, union density, employment protection legislation and unemployment compensations (Røed and Zhang, 2003 and Lalive, Ours

5) See Chung and Jung (2016) for more details about PI.

6) The relationship between market segmentation (primary market vs. secondary market) and involuntary unemployment is described in Bulow and Summers (1985). Wachter (1970) empirically proves that the interindustry wage differential is one of the causes of (involuntary) unemployment. 
and Zweimüller, 2006). ${ }^{7)}$ However in this paper, PI is assumed to reflect the labor market structure after implementing those institutional measures. For example, union density will increase the degree of the labor market duality by protecting workers in the primary market or inner market rather than the outer market workers. The assumption that the labor market situation will affect the decision of market participants is similar to that of Arulampalam and Stewart (1995) that the labor market regime affects unemployment duration.

By considering those macroeconomic variables, more practical policy implications can be drawn. For example, if the polarization of the labor market has large effect on youth unemployment, then the distributional aspect of the labor market should be considered. If growth is the main source of youth unemployment, introducing incentives to competitions or making the labor market more flexible can be policy recommendations. Considering only individual characteristics in terms of job market activities is likely to induce some exhausted policy recommendations such as focusing on matching between job seekers and employers or increasing expenditures on vocational education. In contrast, by looking at the effect of macroeconomic factors, more concrete and realistic policy implications can be drawn.

The following section provides data and variable descriptions. In Section 3, the effect of the labor market situation on the hidden side of youth unemployment such as the duration of maintaining student status and the probability of entering other schools after graduation, is estimated along with traditional variables such as unemployment duration and unemployment rate, with an emphasis on labor market polarization. Section 4 summarizes and concludes.

7) Unemployment compensation might have a role in unemployment duration, but in the case of this paper regarding youth employment, it does not seem to be an affecting factor on college graduates because the benefits are given to those who pay unemployment insurance fees at least for a month. Of course, if unemployment benefits are sufficiently huge, even in a situation where the degree of labor market segmentation is severe, college graduates who cannot get a job in the primary market will have incentive to get any kind of job in the secondary market as they can get higher unemployment benefits after quitting the job. However, for the observed periods, the legislation regarding unemployment benefits is not much changed, and considering the fact that job market activities right after graduation affect the lifetime career of college graduates, short term benefits such as unemployment insurance will not affect college graduates' decision on their career unless the legislations related to unemployment benefits is significantly altered. 


\section{Data and Variables}

College graduates' career path survey data from the Korea Employment Information Service (KEIS) ${ }^{8}$ ) are used to analyze the effect of macroeconomic conditions on college graduates' employment. Four variables related to college graduates' employment are examined, which are the number of semesters between college entrance and graduation $(y 1)$, the number of months between graduation and employment ( $y 2)$, the binomial indicator of getting employed within a year after graduation (y3), and the binomial indicator of entering another school such as graduate school after graduation $(y 4)$.

Total of 126,982 observations collected from year 2005 to year 2013 are used for the analysis. For each year, the survey collects students' job market related activities and tracks the observations for three years. Since the data is constructed based on the survey, some unreliable variables and observations are dropped.9) Additionally, since this paper's research question is about the job market behaviors of fresh college graduates, college graduates aged over 40 are also dropped.

There are some limitations in the sample. One is that there are quite a few observations $(14,593)$ that enroll less than 5 semesters until graduation although college is an 8-semester program. Judging from their age, most of those observations are transferred students; a few other cases seem to be those who pursue degree in their later years after they got expelled out of university early in life. In addition, the relative ranking of school or major cannot be observed in the survey, and some possible career changes or employment/ unemployment status are not considered as well. In order to get rid of possible biasedness caused by these sample problems, additional estimations are also conducted with the sample showing less of those problematic observations (Selected Obs. in the following descriptive statistics table, Table 1).

Control variables are selected following previous studies on youth

8) Graduate Occupational Mobility Survey, survey.keis.or.kr.

9) For example, most of the students do not report their salaries or report unreliable level of salaries of over 10 million KRW/month (equivalent of $10,000 \mathrm{USD} / \mathrm{month}$ ). 


\section{BOK Working Paper No. 2017-4}

\section{Table 1: Sample Statistics (mean)}

\begin{tabular}{|c|c|c|c|}
\hline & $\begin{array}{l}\text { All Observation } \\
(\mathrm{N}=126,982)\end{array}$ & $\begin{array}{l}\text { Obs. Less y } 4=1 \\
(\mathrm{~N}=115,928)\end{array}$ & $\begin{array}{l}\text { Selected Obs. }{ }^{*} \\
(\mathrm{~N}=22,072)\end{array}$ \\
\hline \multicolumn{4}{|l|}{ Dependent Variables } \\
\hline $\begin{array}{l}\text { (y1) No. of semesters } \\
\text { between college entrance and graduation }\end{array}$ & $\begin{array}{l}10.88 \\
(4.14)\end{array}$ & $\begin{array}{l}10.92 \\
(4.18)\end{array}$ & $\begin{array}{l}12.83 \\
(3.33)\end{array}$ \\
\hline $\begin{array}{l}\text { (y2) No. of months } \\
\text { between graduation and employment }\end{array}$ & $\begin{array}{l}9.98 \\
(9.62)\end{array}$ & $\begin{array}{l}9.85 \\
(9.44)\end{array}$ & $\begin{array}{l}8.99 \\
(9.55)\end{array}$ \\
\hline (y3) Employed=1 & $\begin{array}{l}0.79 \\
(0.41)\end{array}$ & $\begin{array}{l}0.81 \\
(0.39)\end{array}$ & $\begin{array}{l}0.83 \\
(0.38)\end{array}$ \\
\hline $\begin{array}{l}\text { (y4) Entering other school after } \\
\text { graduation=1 }\end{array}$ & $\begin{array}{l}0.09 \\
(0.28)\end{array}$ & - & - \\
\hline \multicolumn{4}{|l|}{ Control Variables } \\
\hline (age) Age at graduation (years) & $\begin{array}{l}24.94 \\
(2.58)\end{array}$ & $\begin{array}{l}24.96 \\
(2.60)\end{array}$ & $\begin{array}{l}25.61 \\
(1.95)\end{array}$ \\
\hline (area) School location (Non-Seoul=1) & $\begin{array}{l}0.77 \\
(0.42)\end{array}$ & $\begin{array}{l}0.78 \\
(0.41)\end{array}$ & - \\
\hline (school) Two year degree program $=1$ & $\begin{array}{l}0.27 \\
(0.44)\end{array}$ & $\begin{array}{l}0.27 \\
(0.44)\end{array}$ & - \\
\hline (gender) Gender (female=1) & $\begin{array}{l}0.46 \\
(0.50)\end{array}$ & $\begin{array}{l}0.46 \\
(0.50)\end{array}$ & $\begin{array}{l}0.49 \\
(0.50)\end{array}$ \\
\hline (marriage) Marriage $=1$ & $\begin{array}{l}0.06 \\
(0.25)\end{array}$ & $\begin{array}{l}0.07 \\
(0.25)\end{array}$ & $\begin{array}{l}0.07 \\
(0.25)\end{array}$ \\
\hline (military) Military Service $=1$ & $\begin{array}{l}0.33 \\
(0.47)\end{array}$ & $\begin{array}{l}0.33 \\
(0.47)\end{array}$ & $\begin{array}{l}0.32 \\
(0.46)\end{array}$ \\
\hline \multicolumn{4}{|c|}{ (College Major, Reference Category=Education Major) } \\
\hline (major1) Engineering=1 & $\begin{array}{l}0.27 \\
(0.44)\end{array}$ & $\begin{array}{l}0.27 \\
(0.44)\end{array}$ & $\begin{array}{l}0.23 \\
(0.42)\end{array}$ \\
\hline (major2) Social Science $=1$ & $\begin{array}{l}0.22 \\
(0.42)\end{array}$ & $\begin{array}{l}0.23 \\
(0.42)\end{array}$ & $\begin{array}{l}0.27 \\
(0.44)\end{array}$ \\
\hline $\begin{array}{l}\text { (major3) Fine Arts and Physical } \\
\text { Education }=1\end{array}$ & $\begin{array}{l}0.12 \\
(0.33)\end{array}$ & $\begin{array}{l}0.12 \\
(0.33)\end{array}$ & $\begin{array}{l}0.10 \\
(0.30)\end{array}$ \\
\hline (major4) Medical and Pharmaceutical & 0.06 & 0.07 & 0.03 \\
\hline Science $=1$ & $(0.25)$ & (0.25) & $(0.17)$ \\
\hline (major5) Humanities=1 & $\begin{array}{l}0.11 \\
(0.31)\end{array}$ & $\begin{array}{l}0.11 \\
(0.31)\end{array}$ & $\begin{array}{l}0.16 \\
(0.37)\end{array}$ \\
\hline (major6) Science and Mathematics $=1$ & $\begin{array}{l}0.13 \\
(0.34)\end{array}$ & $\begin{array}{l}0.12 \\
(0.33)\end{array}$ & $\begin{array}{l}0.13 \\
(0.34)\end{array}$ \\
\hline \multicolumn{4}{|c|}{ (Parents' Monthly Income, Reference Category=monthly income between 2-4 mil KRW) } \\
\hline (income1) $>5 \mathrm{mil}=1$ & $\begin{array}{l}0.17 \\
(0.37)\end{array}$ & $\begin{array}{l}0.16 \\
(0.37)\end{array}$ & $\begin{array}{l}0.25 \\
(0.43)\end{array}$ \\
\hline (income2) $4-5$ mil=1 & $\begin{array}{l}0.07 \\
(0.26)\end{array}$ & $\begin{array}{l}0.07 \\
(0.25)\end{array}$ & $\begin{array}{l}0.08 \\
(0.27)\end{array}$ \\
\hline (income3) $\langle 2 m i l=1$ & $\begin{array}{l}0.19 \\
(0.40)\end{array}$ & $\begin{array}{l}0.19 \\
(0.39)\end{array}$ & $\begin{array}{l}0.13 \\
(0.36)\end{array}$ \\
\hline
\end{tabular}

Notes: ( ) are standard deviations.

*: Observations less of $y 4=1, y 1 \leq 5$, school=1, or area $=1$ 
Figure 3: Job Market Related College Students Decision Tree

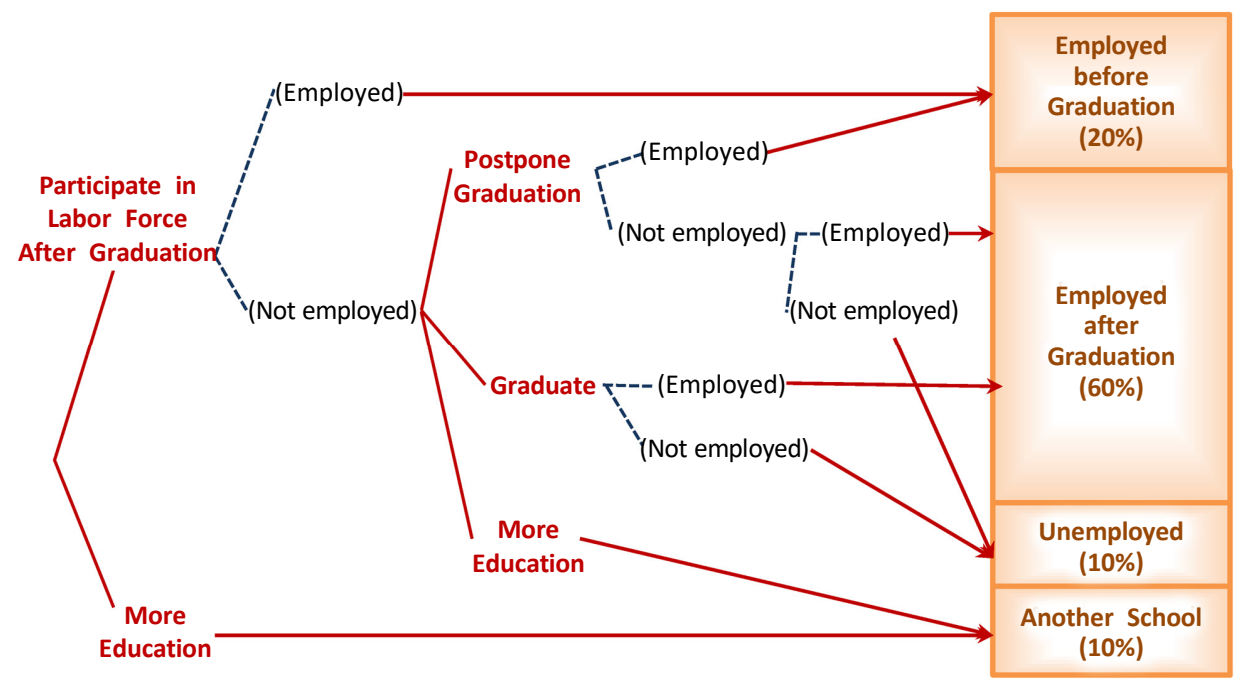

unemployment. Some variables such as parents' income of college graduates that Lee (2010) uses in his analysis of college graduates' employment are also adopted as control variables in the analysis. Regional controls suggested by Berg and Ours (1994) are considered as well.

Some more detailed statistics besides the provided table give us extra information on how college graduates deal with their future careers. Among those 126,982 observations, 100,554 graduates $(79.2 \%)$ are employed within two years after graduation, 11,054 graduates (8.7\%) go to other schools including graduate level schools, and 15,374 graduates (12.1\%) become unemployed (or possibly self-employed). Among those employed, about quarter of them (24,561 graduates, $24.4 \%$ of the employed) are employed before graduation, and about half of them (49,983 graduates, $49.7 \%$ of the employed) within 6 months of graduation. Time to graduation is on average 10.9 semesters, but the figure varies from 9.7 semesters for the class of 2005 to 11.9 semesters for the class of 2007. In order not to include unemployment history on their resume, some college students either postpone graduation until they get employed or enter other tertiary schools. Of course, however, many college 
Figure 4: Labor Market Related Macroeconomic Variables

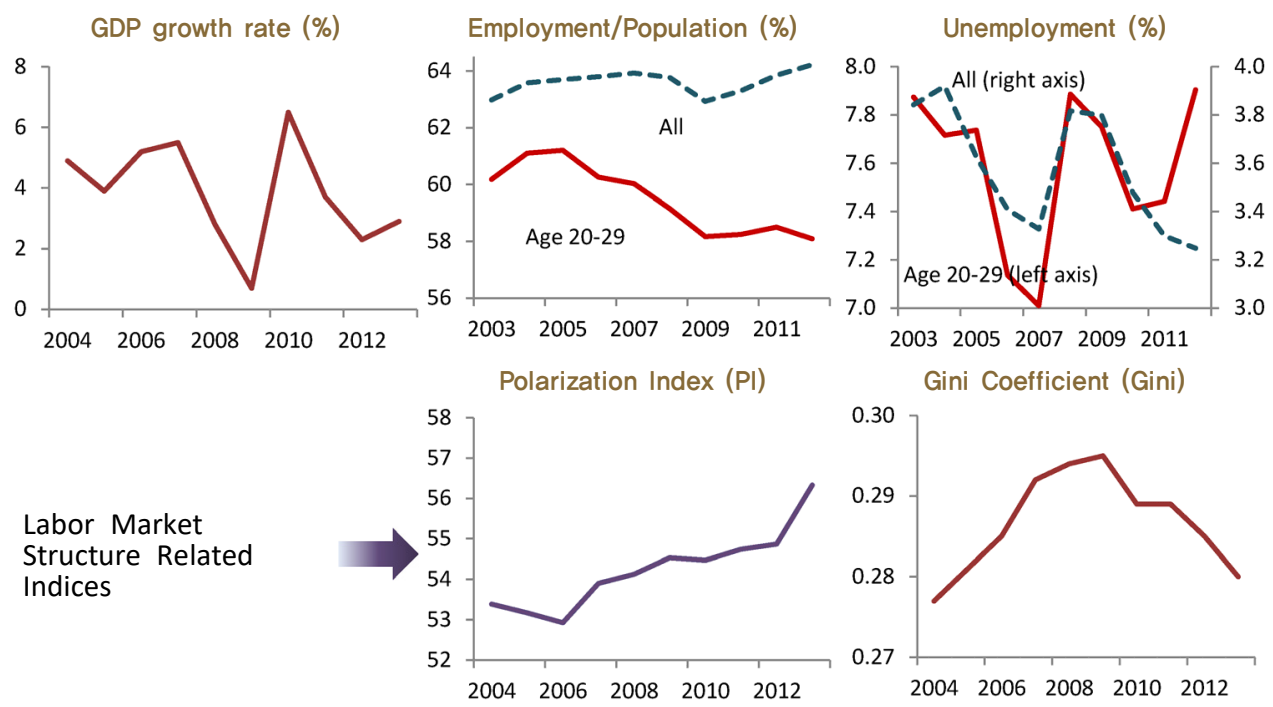

Source : Bank of Korea Economic Statistics, Korean Statistical Information Service and Chung and Jung (2016)

graduates do not have an opportunity for these strategic options, simply ending up being unemployed. A rough summary of the decision tree of college students is described in Figure 3, and this paper tries to cover most of the paths described in the decision tree.

In addition to the survey data, macroeconomic variables are also collected and assigned to each micro observation according to graduation years. The variables are described in Figure 4. Unlike other age groups, the youth job market is sluggish, showing a decrease in the rate of the employment to population ratio since 2004 and an increase in unemployment rates after 2010. GDP growth rate is highly correlated to the unemployment rate, but it does not seem to be related to the employment to population ratio or youth unemployment after 2010. On the other hand, labor market structure indices are delivering somewhat different information about the labor market situation compared to GDP growth rate, possibly providing additional information on the labor market situation. Especially, PI seems to be highly related to the employment to population ratio and a rise in youth unemployment after 2010. 
Figure 5: College Students Job Market Related Activities (Average)

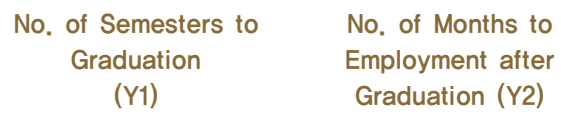

No. of Semesters to Graduation

(Y1)

No. of Months to Employment after Graduation (Y2)

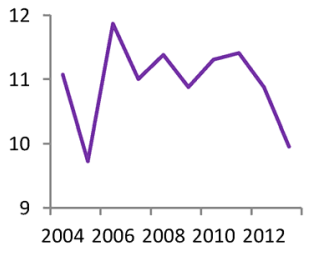

Cross Correlation Matrix

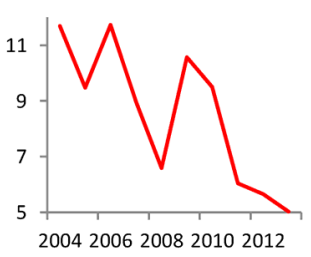

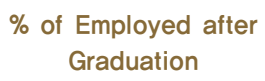
Graduation

(Y3)

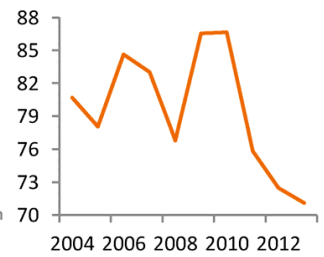

$\%$ of Entering Other Schools after Graduation

(Y4)

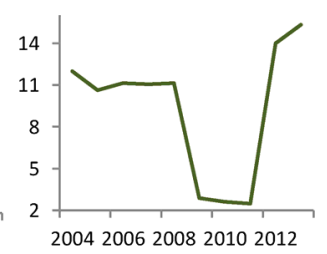

\begin{tabular}{cccc}
\hline & $\mathrm{y} 2$ & $\mathrm{y} 3$ & $\mathrm{y} 4$ \\
\hline $\mathrm{y} 1$ & 0.27 & 0.45 & -0.35 \\
$\mathrm{y} 2$ & & 0.83 & -0.22 \\
$\mathrm{y3}$ & & & -0.57 \\
\hline
\end{tabular}

Gini index, which is expected to represent similar objects to PI, shows a different trend from PI: Gini index decreases after year 2009. Although PI is similar to Gini index as it calculates the distribution of wage income, they are different in that PI is relatively free from the lifetime income hypothesis that young workers earn less than experienced workers. For example, an entry level young worker working for a big corporation with a standard working contract can be positioned in a middle to low income worker category in Gini index, but placed in the primary market labor in PI. In this paper, when Gini index is adopted as a proxy to the labor market structure, an alternative to PI, it does not render feasible results probably because of this difference between PI and Gini.

Regarding other explanatory variables, proper control and modelling is needed in the analysis, since the relationship between college students' job market related outcomes is the result of a complex interaction between personal characteristics and market situation. Among those college students' job market related activities, binomial choice variables such as the probability of getting employed after graduation (y3) and the ratio of entering other schools after graduation $(y 4)$ seem to be highly correlated to the youth unemployment rate (Figure 5). However, the duration variables ( $y 1$ and $y 2$ ) do not seem to deliver a 
Table 2: Expected Signs

\begin{tabular}{lcc} 
& GDP & PI \\
Length of maintaining student status & $?$ & + \\
Length of job searching after graduation & $?$ & - \\
Employed after graduation & + & - \\
Entering another school after graduation & - & + \\
\hline
\end{tabular}

conforming message compared to the youth unemployment rate, thus necessitating proper control for the age and the number of periods of enrollment in analyzing dependent variables. For example, in a situation where a sluggish labor market has been prolonged for a long period of time and students have already enrolled many semesters, they might have to enter the job market even though the labor market situation is bad. As another example, an unemployed college graduate might want to get a job in a secondary market when the length of the unemployment period becomes longer and the market situation is expected to become worse. In other words, many disturbing factors make it hard to recognize the relationship between the dependent and independent variables.

The expected effects of the labor market situation on the dependent variables are summarized in Table 2. It is obvious that for the employment probability (y3) and the probability of entering another school $(y 4)$, the business cycle effect should be positive and negative respectively. Likewise, since GDP represents the firms' demand for labor, its immediate effect should be negative on the duration of both student status and unemployment after graduation. However, from the workers' point of view, since the business cycle phase constitutes their expectations of the job market prospect, they may extend their job searching in the hope for better opportunities after receiving a good sign from the labor demand. Thus, the overall effect of the business cycle variable on the duration variables ( $y 1$ and $y 2$ ) is ambiguous.

On the contrary, the labor market structure indicator (PI) only affects the labor supply side of workers in this paper as using individual observations in the analysis. Thus, it is expected that as the labor market becomes more 
polarized, the duration of maintaining student status should be longer since college students will prepare more for the job market; the length of searching period after graduation should be shorter since minimizing the unemployment period is better for young workers. Also, PI will have negative and positive effect on the probability of employment and the probability of entering another school, respectively, since the chances for their career should be limited when labor market polarization is severe.

\section{Estimation Results}

\section{Estimation results on the duration of maintaining student status}

Conceptually, the decision between maintaining student status versus graduation should be determined by (1) probability of getting a good job, (2) cost of maintaining student status, (3) institutional factors and (4) personal characteristics. Probability of getting a good job should be affected by the labor market situation represented by GDP growth rate and PI in our case, as well as other personal status and characteristics. One example of the cost of maintaining student status is registration fee, but it is not controlled in our case: its variance is not that large compared to the lifetime income after graduation; and the upward trend of registration fee resembles the PI trend during our sample period. Institutional factors include the type of college program, i.e. two-year program or four-year program, and whether students have to serve the military obligation which lasts for approximately two years. Personal characteristics include age, gender, marriage status, major and parents' income.

First thing to consider when using the variables representing the labor market situation is that they constitute the expectations of potential workers. If we assume that students have rational expectations, then the expected market situation at the time of graduation should be equal to the actual market situation. In this case, we should match the current GDP growth rate

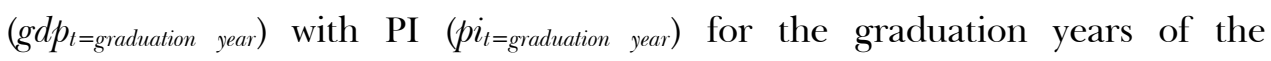


observations. On the contrary, if we adopt the adaptive expectations assumption, the expectation for the labor market situation should be constructed based on the past performances of the market. Thus, we should match the past GDP growth rate ( $\left.g d p_{t=\text { past year }}\right)$ with PI ( $p i_{t=\text { past year }}$ ) for the graduation years of the observations. This paper provides the estimation results based on the rational expectations assumption, but the results under the other assumption are also provided to check the robustness of the estimation results.

Another thing to consider when estimating the effect of the labor market situation on the variables of interests is that the variables representing the labor market situation are time variant, whereas the control variables are time invariant. Thus, it should be considered that the external situation can have different context depending on students' grades. For instance, if a student has been enrolled for a long time, say $5 \sim 6$ years, it can negatively affect his/her job market performance, thus regardless of the labor market situation, he/she will have to graduate anyway. In this paper's analysis, the macroeconomic variables are treated as time-varying. 10)

In this sense, from the basic proportional hazard regression (1), we use equation (2) using GDP growth rate and PI as time-varying variables (z). Since the actual impact of macroeconomic situations on students' decision to graduate is diminishing with the duration period, an exponential rate of $g(t)=\exp (-0.35 \times t)$ is considered, which assumes the half-life of the macroeconomic impact is one year (two semesters). Other hyper parameters such as -0.2 and -0.5 are also considered alternatives to -0.35 to check the robustness of the estimation results.

Basic Proportional Hazard Regression:

$$
h(t)=h_{0}(t) \exp \left(\beta_{1} x_{1}+\cdots+\beta_{k} x_{k}\right)
$$

10) One statistical method to test whether GDP growth rate ( $g d p)$ and PI (pi) variables are time-varying is to check the significance of $\gamma_{1}$ and $\gamma_{2}$ in equation $(*)$. The estimation results of $\left(^{*}\right)$ suggest to reject the null hypotheses of $H_{0}: \gamma_{g d p}=0$ and $H_{0}: \gamma_{p i}=0$ at $5 \%$ significance level.

$h(t)=h_{0}(t) \exp \left(X B+\beta_{1} g d p+\beta_{2} p i+g(t)\left(\gamma_{1} g d p+\gamma_{2} p i\right)\right) \quad(*)$

$\Rightarrow h(t)=h_{0}(t) \exp (X B-0.015 g d p+5.201 p i+g(t)(0.124 g d p-0.570 p i))$

Note : ( ) are standard errors. 
where $h(t)$ is the baseline hazard function, and is control variables.

Addition of Time-varying Variables, $z_{1}, \cdots, z_{l}$ :

$$
h(t)=h_{0}(t) \exp \left(\beta_{1} x_{1}+\cdots+\beta_{k} x_{k}+g(t)\left(\gamma_{1} z_{1}+\cdots+\gamma_{l} z_{l}\right)\right)
$$

where $g(t)$ interacts with the time-varying covariates.

Using equation (2), the estimation results are presented in Table 3.11)

Except for column (1) where only institutional variables are controlled, GDP growth rate increases the hazard rate while PI decreases it, agreeing with the logical expectations. Control variables are also in concord with general expectations. It turns out that labor market polarization has statistically significant effect on delaying graduation.

However, for the GDP growth rate, adapting other model assumptions generates different implications, as shown in Table 4 . To check the robustness of the estimation results, other models using adaptive expectations assumption, alternative data sets, alternative proxy variables and alternative diminishing rates are estimated using the same control variables as in column (4) of the original estimation table. The implications for PI are not different from the original estimation in the direction of the effect. However, adopting adaptive expectations assumption alters the direction of the effect of the GDP growth rate, implying that higher GDP growth rate extends the period of maintaining student status. Also, when using the selected samples of students getting into four year program universities in Seoul, higher GDP growth rate leads to longer duration. Thus, the effect of GDP growth on the duration of maintaining student status is ambiguous.

11) The regression can be reduced to how much the macroeconomic variables can mimic the group fixed effects assigned to each graduation year. Thus, the regression model can be reduced to the problem, whether the linear combination of GDP growth rate and PI can reproduce the ten years of graduation year fixed effects. It turned out that the use of those two variables can explain most of the year fixed effects. More details are provided in Appendix 1. 


\section{$15 \quad$ BOK Working Paper No. 2017-4}

Table 3: The Effect of Labor Market Polarization on Maintaining Student Status

\begin{tabular}{|c|c|c|c|c|c|c|c|c|}
\hline & $\begin{array}{c}\text { (1) } \\
\text { Hazard Ratio }\end{array}$ & & $\begin{array}{c}\text { (2) } \\
\text { Hazard Ratio }\end{array}$ & & $\begin{array}{c}\text { (3) } \\
\text { Hazard Ratio }\end{array}$ & & $\begin{array}{c}\text { (4) } \\
\text { Hazard Ratio }\end{array}$ & \\
\hline \multicolumn{9}{|c|}{ (Control Variables) } \\
\hline age & & & $\begin{array}{r}0.684 \\
(0.002)\end{array}$ & $* *$ & $\begin{array}{r}0.686 \\
(0.002)\end{array}$ & ** & $\begin{array}{r}0.686 \\
(0.002)\end{array}$ & $* *$ \\
\hline area & & & $\begin{array}{r}1.120 \\
(0.009)\end{array}$ & $* *$ & $\begin{array}{r}1.110 \\
(0.009)\end{array}$ & $* *$ & $\begin{array}{r}1.110 \\
(0.009)\end{array}$ & $* *$ \\
\hline school & $\begin{array}{r}3.352 \\
(0.024)\end{array}$ & $* *$ & $\begin{array}{r}3.022 \\
(0.025)\end{array}$ & $* *$ & $\begin{array}{r}3.050 \\
(0.026)\end{array}$ & $* *$ & $\begin{array}{r}3.050 \\
(0.026)\end{array}$ & $* *$ \\
\hline female & & & $\begin{array}{r}2.808 \\
(0.027)\end{array}$ & $* *$ & $\begin{array}{r}2.689 \\
(0.027)\end{array}$ & $* *$ & $\begin{array}{r}2.683 \\
(0.027)\end{array}$ & $* *$ \\
\hline marriage & & & $\begin{array}{r}1.110 \\
(0.014)\end{array}$ & $* *$ & $\begin{array}{r}1.105 \\
(0.014)\end{array}$ & ** & $\begin{array}{r}1.105 \\
(0.014)\end{array}$ & $* *$ \\
\hline military & $\begin{array}{r}0.418 \\
(0.003)\end{array}$ & ** & $\begin{array}{r}0.833 \\
(0.007)\end{array}$ & ** & $\begin{array}{r}0.833 \\
(0.007)\end{array}$ & ** & $\begin{array}{r}0.830 \\
(0.008)\end{array}$ & $* *$ \\
\hline major1 & & & & & $\begin{array}{r}0.636 \\
(0.008)\end{array}$ & ** & $\begin{array}{r}0.636 \\
(0.008)\end{array}$ & ** \\
\hline major2 & & & & & $\begin{array}{r}0.679 \\
(0.009)\end{array}$ & $* *$ & $\begin{array}{r}0.679 \\
(0.009)\end{array}$ & $* *$ \\
\hline major3 & & & & & $\begin{array}{r}0.748 \\
(0.011)\end{array}$ & $* *$ & $\begin{array}{r}0.748 \\
(0.011)\end{array}$ & $* *$ \\
\hline major4 & & & & & $\begin{array}{r}0.778 \\
(0.013)\end{array}$ & $* *$ & $\begin{array}{r}0.778 \\
(0.013)\end{array}$ & $* *$ \\
\hline major5 & & & & & $\begin{array}{r}0.650 \\
(0.009)\end{array}$ & $* *$ & $\begin{array}{r}0.650 \\
(0.009)\end{array}$ & $* *$ \\
\hline major6 & & & & & $\begin{array}{l}0.715 \\
(0.01)\end{array}$ & $* *$ & $\begin{array}{l}0.716 \\
(0.01)\end{array}$ & $* *$ \\
\hline income1 & & & & & & & $\begin{array}{r}1.018 \\
(0.009)\end{array}$ & ** \\
\hline income2 & & & & & & & $\begin{array}{r}1.010 \\
(0.013)\end{array}$ & * \\
\hline income3 & & & & & & & $\begin{array}{r}1.019 \\
(0.009)\end{array}$ & $* *$ \\
\hline \multicolumn{9}{|c|}{ (Time Varying Variables) } \\
\hline gdp & $\begin{array}{r}1.176 \\
(0.022)\end{array}$ & ** & $\begin{array}{l}1.033 \\
(0.02)\end{array}$ & * & $\begin{array}{l}1.039 \\
(0.02)\end{array}$ & ** & $\begin{array}{l}1.032 \\
(0.02)\end{array}$ & * \\
\hline pi & $\begin{array}{r}2.132 \\
(0.082)\end{array}$ & ** & $\begin{array}{l}0.769 \\
(0.03)\end{array}$ & $* *$ & $\begin{array}{r}0.751 \\
(0.029)\end{array}$ & $* *$ & $\begin{array}{l}0.756 \\
(0.03)\end{array}$ & ** \\
\hline Likelihood & $-1,230,750$ & & $-1,201,351$ & & $-1,200,615$ & & $-1,200,610$ & \\
\hline
\end{tabular}

Notes: ( ) are standard errors.

Dependent Variable $=$ No. of semesters between college entrance and graduation.

No. of observations $=115,928$ / Cox regression with uncensored data.

Variables in TVC equation are interacted with exp $(-0.35 * \mathrm{y} 1)$.

** : significant at $5 \% /{ }^{*}$ : significant at $10 \%$. 


\section{Table 4: Robustness Check for the Effect of Labor Market Polarization on Maintaining Student Status}

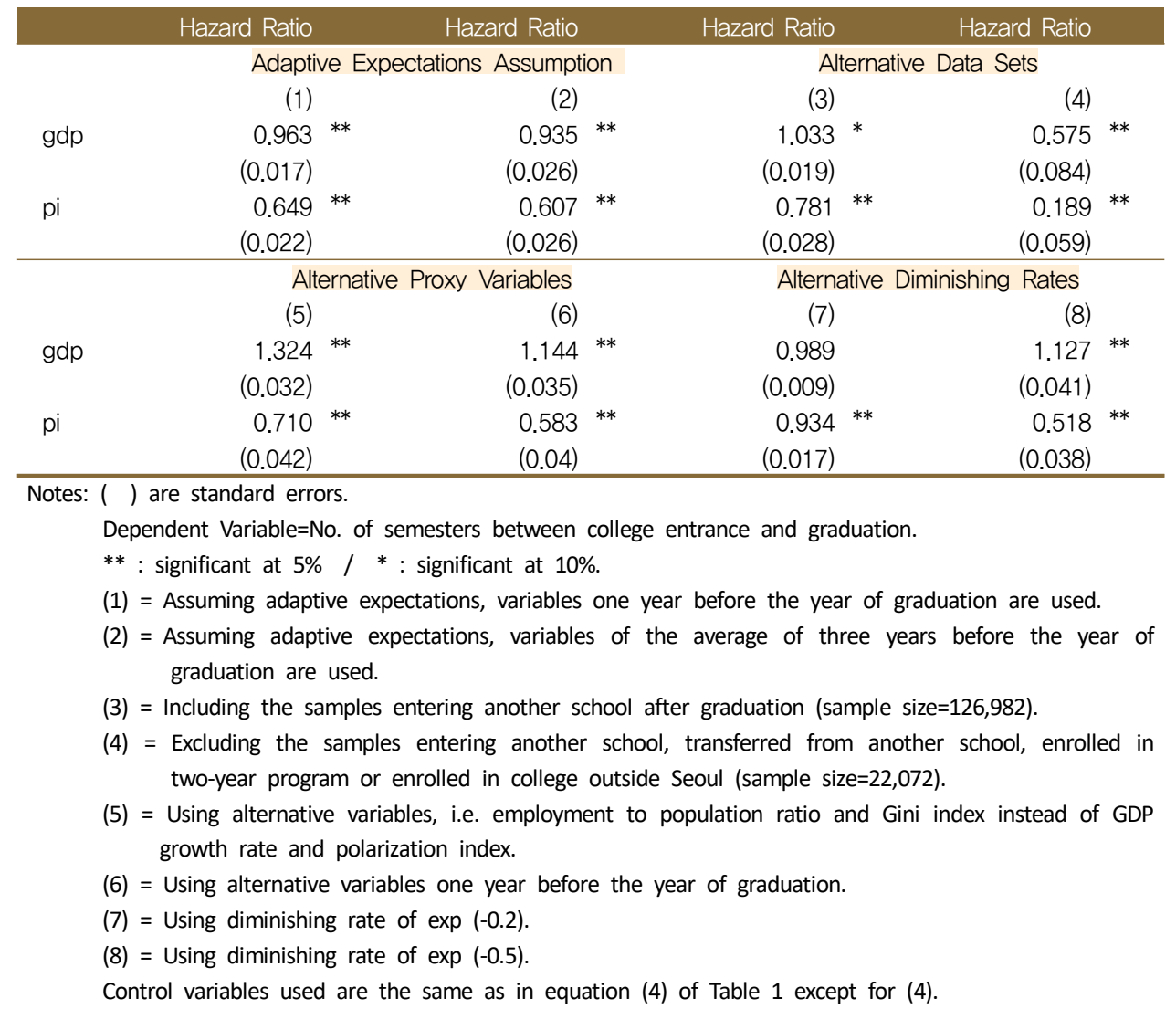

2. Estimation results on the unemployment duration, the probability of getting employed and probability of entering other school after graduation

In binomial choice variable cases, the samples used in the probability of getting employed are different from those for the probability of entering other schools after graduation in that the former involves only college graduates who decide to participate in the labor force. Thus, the samples entering other schools after graduation are not included in the analysis. However, it should be also noted that the probability of getting employed after graduation might be underestimated since some of the college graduates might not participate in the 
Table 5: The Effect of Labor Market Polarization on the Unemployment Duration

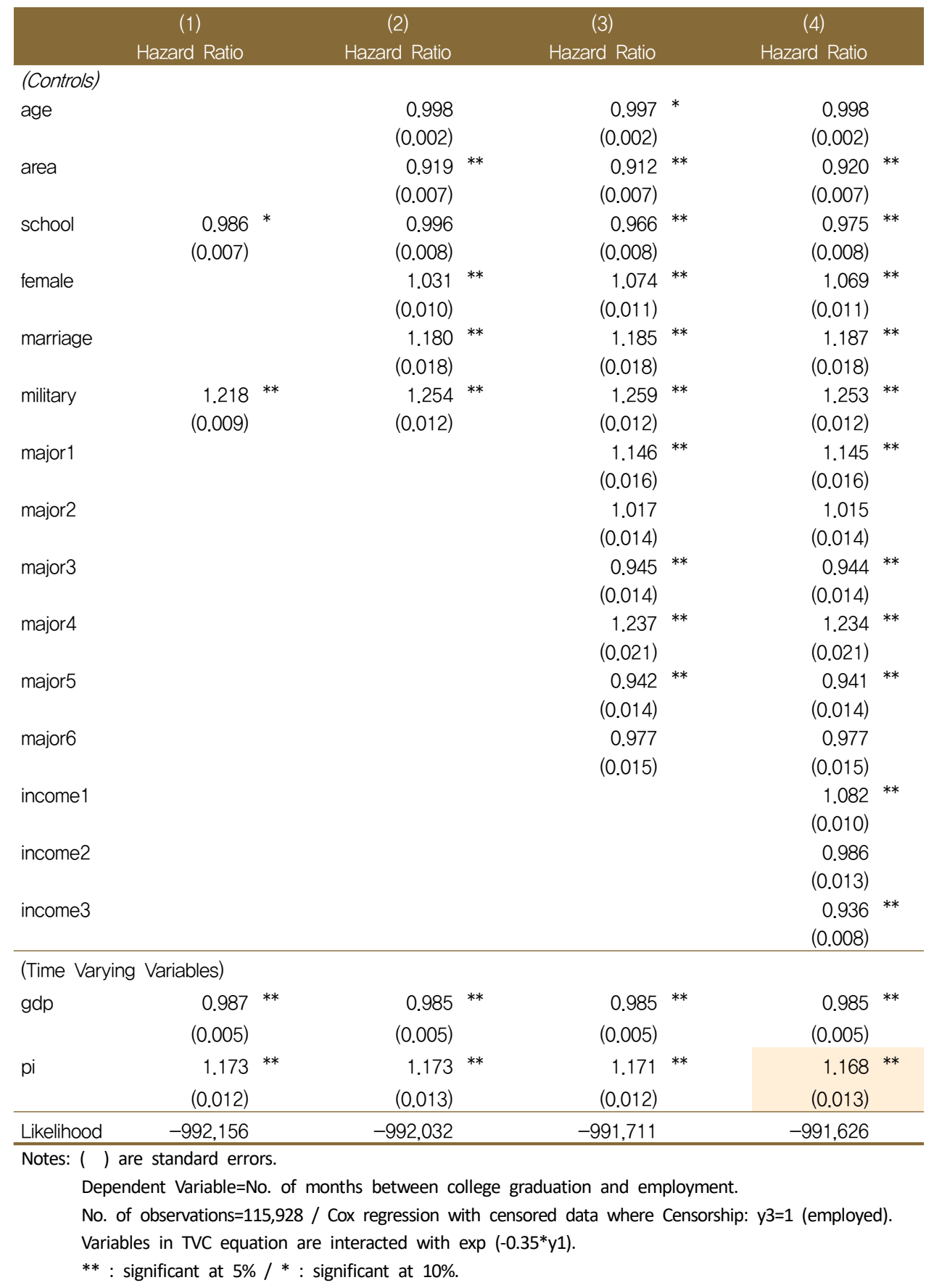


labor force in case available job openings offer lower wage than their reserve wage, thus the estimated coefficients can be biased down. ${ }^{12)}$

Using equation (2), with the same logic as the time-varying nature of macroeconomic variables that the longer the unemployment period is, the less a job seeker becomes selective in choosing a job, the effect of PI on the unemployment duration turns out to be the same as the expectations. ${ }^{13)}$ The direction of the effect of GDP growth rate and PI is opposite to previous results, implying that a higher GDP growth rate delays the employment process while a higher PI accelerates the process. The estimation results are presented in Table 5.

For the probability of getting employed after graduation, and for the probability of entering another school after graduation, GDP growth rate and PI also exhibit expected signs. Controlling personal characteristics (column 1 and 5), school characteristics (column 2 and 6), major (column 3 and 7) and parents income (column 4 and 8) all generates similar implications for respective estimations. In these binary variables case, as the GDP growth rate represents the firm side of the labor demand, it should be positive in employment probability and negative in the probability of entering another program. Likewise, since PI represents the labor market structure, a bad situation or a high value of PI should enhance competitions for a good job and incentives to avoid the competitions. ${ }^{14)}$

12) This logic is also applied to the unemployment duration when a college graduate simply decides not to participate in the labor force after graduation.

13) Unlike the duration of maintaining student status ( $y 1)$, the unemployment duration ( $y 2)$ is censored when the observation is employed.

14) To check the robustness of the estimation results, an alternative set of models is also constructed and estimated. In most of the cases, GDP growth rate and PI render similar implications. However, when using the alternative proxy variables of the employment to population ratio and Gini index for GDP growth rate and PI, the implications are changed (See Appendix 2 for the estimation results).

One possible reason that PI and Gini show different implications is that as workers get older, they receive higher wage in compensation for the human capital associated with their working experiences. Thus, secondary market workers with seniority based wage schedule might enlarge the gap between PI and Gini since a rise in income does not automatically reclassify the workers as primary market workers. This can explain why PI is increasing consistently while Gini is dropping recently, but detailed analysis on PI and Gini is out of the range of this paper's interest, thus should be left for future research. 
Table 6: The Effect of Labor Market Polarization on the Probability of Employment after Graduation

\begin{tabular}{|c|c|c|c|c|c|c|c|c|}
\hline & \multicolumn{4}{|c|}{ logit } & \multicolumn{4}{|c|}{ probit } \\
\hline & (1) & (2) & (3) & (4) & (5) & (6) & (7) & (8) \\
\hline constant & $\begin{array}{l}7.409^{* *} \\
(0.562)\end{array}$ & $\begin{array}{l}7.453^{* *} \\
(0.562)\end{array}$ & $\begin{array}{l}7.805^{* *} \\
(0.566)\end{array}$ & $\begin{array}{l}7.398^{* *} \\
(0.574)\end{array}$ & $\begin{array}{l}4.176^{* *} \\
(0.317)\end{array}$ & $\begin{array}{c}4.224^{* *} \\
(0.318)\end{array}$ & $\begin{array}{l}4.417^{* *} \\
(0.320)\end{array}$ & $\begin{array}{c}4.228^{* *} \\
(0.325)\end{array}$ \\
\hline age & $\begin{array}{l}-0.040^{* *} \\
(0.003)\end{array}$ & $\begin{array}{l}-0.048^{* *} \\
(0.003)\end{array}$ & $\begin{array}{l}-0.049^{* *} \\
(0.003)\end{array}$ & $\begin{array}{l}-0.046^{* *} \\
(0.003)\end{array}$ & $\begin{array}{l}-0.023^{* *} \\
(0.002)\end{array}$ & $\begin{array}{l}-0.028^{* *} \\
(0.002)\end{array}$ & $\begin{array}{l}-0.028^{* *} \\
(0.002)\end{array}$ & $\begin{array}{l}-0.026^{* *} \\
(0.002)\end{array}$ \\
\hline area & & $\begin{array}{l}-0.080^{* *} \\
(0.019)\end{array}$ & $\begin{array}{l}-0.104^{* *} \\
(0.019)\end{array}$ & $\begin{array}{l}-0.089^{* *} \\
(0.019)\end{array}$ & & $\begin{array}{l}-0.046^{* *} \\
(0.011)\end{array}$ & $\begin{array}{l}-0.058^{* *} \\
(0.011)\end{array}$ & $\begin{array}{l}-0.050^{* *} \\
(0.011)\end{array}$ \\
\hline school & & $\begin{array}{l}-0.123^{* *} \\
(0.018)\end{array}$ & $\begin{array}{l}-0.211^{* *} \\
(0.018)\end{array}$ & $\begin{array}{l}-0.195^{* *} \\
(0.018)\end{array}$ & & $\begin{array}{l}-0.071^{* *} \\
(0.010)\end{array}$ & $\begin{array}{l}-0.121^{* *} \\
(0.010)\end{array}$ & $\begin{array}{l}-0.112^{* *} \\
(0.010)\end{array}$ \\
\hline female & $\begin{array}{l}-0.326^{* *} \\
(0.023)\end{array}$ & $\begin{array}{l}-0.344^{* *} \\
(0.023)\end{array}$ & $\begin{array}{l}-0.299^{* *} \\
(0.024)\end{array}$ & $\begin{array}{l}-0.300^{* *} \\
(0.024)\end{array}$ & $\begin{array}{l}-0.180^{* *} \\
(0.013)\end{array}$ & $\begin{array}{l}-0.192^{* *} \\
(0.013)\end{array}$ & $\begin{array}{l}-0.166^{* *} \\
(0.013)\end{array}$ & $\begin{array}{l}-0.167^{* *} \\
(0.013)\end{array}$ \\
\hline marriage & $\begin{array}{l}-0.522^{* *} \\
(0.029)\end{array}$ & $\begin{array}{l}-0.486 * * \\
(0.030)\end{array}$ & $\begin{array}{l}-0.482^{* *} \\
(0.030)\end{array}$ & $\begin{array}{l}-0.481^{* *} \\
(0.030)\end{array}$ & $\begin{array}{l}-0.305^{* *} \\
(0.017)\end{array}$ & $\begin{array}{l}-0.282^{* *} \\
(0.018)\end{array}$ & $\begin{array}{l}-0.280^{* *} \\
(0.018)\end{array}$ & $\begin{array}{l}-0.279^{* *} \\
(0.018)\end{array}$ \\
\hline military & $\begin{array}{l}-0.160^{* *} \\
(0.024)\end{array}$ & $\begin{array}{l}-0.164^{* *} \\
(0.024)\end{array}$ & $\begin{array}{l}-0.153^{* *} \\
(0.024)\end{array}$ & $\begin{array}{l}-0.149^{* *} \\
(0.024)\end{array}$ & $\begin{array}{l}-0.089^{* *} \\
(0.013)\end{array}$ & $\begin{array}{l}-0.091^{* *} \\
(0.013)\end{array}$ & $\begin{array}{l}-0.085^{* *} \\
(0.013)\end{array}$ & $\begin{array}{l}-0.082^{* *} \\
(0.013)\end{array}$ \\
\hline major1 & & & $\begin{array}{l}0.146^{* *} \\
(0.032)\end{array}$ & $\begin{array}{l}0.148^{* *} \\
(0.032)\end{array}$ & & & $\begin{array}{l}0.086^{* *} \\
(0.018)\end{array}$ & $\begin{array}{c}0.087^{* *} \\
(0.018)\end{array}$ \\
\hline major2 & & & $\begin{array}{l}-0.083^{* *} \\
(0.031)\end{array}$ & $\begin{array}{l}-0.082^{* *} \\
(0.031)\end{array}$ & & & $\begin{array}{l}-0.042^{* *} \\
(0.017)\end{array}$ & $\begin{array}{l}-0.042^{* *} \\
(0.017)\end{array}$ \\
\hline major3 & & & $\begin{array}{l}-0.028 \\
(0.034)\end{array}$ & $\begin{array}{l}-0.027 \\
(0.034)\end{array}$ & & & $\begin{array}{l}-0.011 \\
(0.019)\end{array}$ & $\begin{array}{l}-0.010 \\
(0.019)\end{array}$ \\
\hline major4 & & & $\begin{array}{l}0.727^{* *} \\
(0.046)\end{array}$ & $\begin{array}{c}0.725^{* *} \\
(0.046)\end{array}$ & & & $\begin{array}{c}0.402^{* *} \\
(0.025)\end{array}$ & $\begin{array}{c}0.401^{* *} \\
(0.025)\end{array}$ \\
\hline major5 & & & $\begin{array}{l}-0.197^{* *} \\
(0.034)\end{array}$ & $\begin{array}{l}-0.197^{* *} \\
(0.034)\end{array}$ & & & $\begin{array}{l}-0.107^{* *} \\
(0.020)\end{array}$ & $\begin{array}{l}-0.107^{* *} \\
(0.020)\end{array}$ \\
\hline major6 & & & $\begin{array}{l}-0.171^{* *} \\
(0.034)\end{array}$ & $\begin{array}{l}-0.170^{* *} \\
(0.034)\end{array}$ & & & $\begin{array}{l}-0.095^{* *} \\
(0.019)\end{array}$ & $\begin{array}{l}-0.094^{* *} \\
(0.019)\end{array}$ \\
\hline income1 & & & & $\begin{array}{l}0.107^{* *} \\
(0.023)\end{array}$ & & & & $\begin{array}{c}0.059^{* *} \\
(0.013)\end{array}$ \\
\hline income2 & & & & $\begin{array}{l}0.194^{* *} \\
(0.034)\end{array}$ & & & & $\begin{array}{c}0.106^{* *} \\
(0.019)\end{array}$ \\
\hline income3 & & & & $\begin{array}{l}-0.119^{* *} \\
(0.020)\end{array}$ & & & & $\begin{array}{l}-0.070^{* *} \\
(0.011)\end{array}$ \\
\hline gdp & $0.035^{* *}$ & $0.034^{* *}$ & $0.034^{* *}$ & $0.032^{* *}$ & $0.020^{* *}$ & $0.020^{* *}$ & $0.020^{* *}$ & $0.019^{* *}$ \\
\hline & $(0.005)$ & $(0.005)$ & $(0.005)$ & $(0.005)$ & (0.003) & $(0.003)$ & $(0.003)$ & $(0.003)$ \\
\hline pi & $-0.088^{* *}$ & $-0.084^{* *}$ & $-0.090^{* *}$ & $-0.084^{* *}$ & $-0.049^{* *}$ & $-0.046^{* *}$ & $-0.050^{* *}$ & $-0.047^{* *}$ \\
\hline & $(0.010)$ & $(0.010)$ & $(0.010)$ & $(0.010)$ & $(0.006)$ & $(0.006)$ & $(0.006)$ & $(0.006)$ \\
\hline Likelihood & $-55,316$ & $-55,277$ & $-54,931$ & $-54,873$ & $-55,323$ & $-55,284$ & $-54,983$ & $-54,879$ \\
\hline
\end{tabular}

Notes: ( ) are standard errors.

Dependent Variable=Binary variable, Employed within a year after graduation=1.

No. of observations $=115,928$.

** : significant at $5 \% /{ }^{*}$ : significant at $10 \%$. 
Table 7: The Effect of Labor Market Polarization on the Probability of Entering another School after Graduation

\begin{tabular}{|c|c|c|c|c|c|c|c|c|}
\hline & \multicolumn{4}{|c|}{ logit } & \multicolumn{4}{|c|}{ probit } \\
\hline & (1) & (2) & (3) & (4) & (5) & (6) & (7) & (8) \\
\hline \multirow[t]{2}{*}{ constant } & $-6.760^{* *}$ & $-4.214^{* *}$ & $-4.291^{* *}$ & $-5.632^{* *}$ & $-3.343^{* *}$ & $-2.405^{* *}$ & $-2.380^{* *}$ & $-3.074^{* *}$ \\
\hline & $(0.722)$ & $(0.734)$ & (0.738) & $(0.741)$ & $(0.355)$ & $(0.361)$ & $(0.364)$ & $(0.369)$ \\
\hline \multirow[t]{2}{*}{ age } & $-0.040^{* *}$ & $-0.133^{* *}$ & $-0.124^{* *}$ & $-0.121^{* *}$ & $-0.019^{* *}$ & $-0.052^{* *}$ & $-0.048^{* *}$ & $-0.048^{* *}$ \\
\hline & $(0.005)$ & $(0.007)$ & $(0.007)$ & $(0.007)$ & (0.002) & (0.003) & $(0.003)$ & $(0.003)$ \\
\hline \multirow[t]{2}{*}{ area } & & $-0.458^{* *}$ & $-0.470^{* *}$ & $-0.442^{* *}$ & & $-0.223^{* *}$ & $-0.231^{* *}$ & $-0.218^{* *}$ \\
\hline & & $(0.022)$ & $(0.022)$ & $(0.023)$ & & $(0.012)$ & $(0.012)$ & $(0.012)$ \\
\hline \multirow[t]{2}{*}{ school } & & $-0.760^{* *}$ & $-0.717^{* *}$ & $-0.694^{* *}$ & & $-0.339^{* *}$ & $-0.314^{* *}$ & $-0.305^{* *}$ \\
\hline & & $(0.029)$ & $(0.030)$ & $(0.030)$ & & $(0.014)$ & $(0.014)$ & $(0.014)$ \\
\hline \multirow[t]{2}{*}{ female } & $-0.194^{* *}$ & $-0.388^{* *}$ & $-0.405^{* *}$ & $-0.451^{* *}$ & $-0.091^{* *}$ & $-0.159^{* *}$ & $-0.168^{* *}$ & $-0.194^{* *}$ \\
\hline & $(0.029)$ & $(0.030)$ & $(0.031)$ & $(0.031)$ & $(0.014)$ & $(0.015)$ & $(0.015)$ & $(0.015)$ \\
\hline \multirow[t]{2}{*}{ marriage } & $-0.289^{* *}$ & $-0.113^{* *}$ & $-0.100^{* *}$ & $-0.098^{* *}$ & $-0.138^{* *}$ & $-0.042^{*}$ & -0.033 & -0.033 \\
\hline & $(0.050)$ & $(0.049)$ & $(0.050)$ & $(0.050)$ & $(0.024)$ & $(0.024)$ & $(0.024)$ & $(0.024)$ \\
\hline \multirow[t]{2}{*}{ military } & $-0.128^{* *}$ & $-0.088^{* *}$ & $-0.086^{* *}$ & $-0.172^{* *}$ & $-0.062^{* *}$ & $-0.049^{* *}$ & $-0.048^{* *}$ & $-0.090^{* *}$ \\
\hline & $(0.030)$ & $(0.030)$ & $(0.030)$ & $(0.030)$ & $(0.015)$ & $(0.015)$ & $(0.015)$ & $(0.015)$ \\
\hline \multirow[t]{2}{*}{ major1 } & & & $0.075^{*}$ & $0.085^{* *}$ & & & 0.023 & 0.027 \\
\hline & & & $(0.042)$ & $(0.042)$ & & & $(0.021)$ & $(0.021)$ \\
\hline \multirow[t]{2}{*}{ major2 } & & & $-0.506^{* *}$ & $-0.500^{* *}$ & & & $-0.248^{* *}$ & $-0.248^{* *}$ \\
\hline & & & $(0.046)$ & $(0.046)$ & & & $(0.022)$ & $(0.022)$ \\
\hline \multirow[t]{2}{*}{ major3 } & & & $0.230^{* *}$ & $0.230^{* *}$ & & & $0.105^{* *}$ & $0.105^{* *}$ \\
\hline & & & $(0.046)$ & $(0.046)$ & & & $(0.023)$ & $(0.023)$ \\
\hline \multirow[t]{2}{*}{ major4 } & & & $0.198^{* *}$ & $0.184^{* *}$ & & & $0.081^{* *}$ & $0.074^{* *}$ \\
\hline & & & $(0.056)$ & $(0.056)$ & & & $(0.028)$ & $(0.028)$ \\
\hline \multirow[t]{2}{*}{ major5 } & & & $0.280^{* *}$ & $0.285^{* *}$ & & & $0.134^{* *}$ & $0.137^{* *}$ \\
\hline & & & $(0.045)$ & $(0.045)$ & & & $(0.023)$ & $(0.023)$ \\
\hline \multirow[t]{2}{*}{ major6 } & & & $0.601^{* *}$ & $0.607^{* *}$ & & & $0.301^{* *}$ & $0.304^{* *}$ \\
\hline & & & $(0.042)$ & $(0.042)$ & & & $(0.022)$ & $(0.022)$ \\
\hline \multirow[t]{2}{*}{ income1 } & & & & $0.462^{* *}$ & & & & $0.238^{* *}$ \\
\hline & & & & $(0.027)$ & & & & $(0.014)$ \\
\hline \multirow[t]{2}{*}{ income2 } & & & & $0.343^{* *}$ & & & & $0.176^{* *}$ \\
\hline & & & & $(0.041)$ & & & & $(0.021)$ \\
\hline \multirow[t]{2}{*}{ income3 } & & & & $0.360^{* *}$ & & & & $0.181^{* *}$ \\
\hline & & & & $(0.027)$ & & & & $(0.014)$ \\
\hline \multirow[t]{2}{*}{ gdp } & $-0.023^{* *}$ & $-0.029^{* *}$ & $-0.027^{* *}$ & $-0.052^{* *}$ & $-0.013^{* *}$ & $-0.015^{* *}$ & $-0.014^{* *}$ & $-0.026^{* *}$ \\
\hline & $(0.006)$ & $(0.006)$ & $(0.006)$ & $(0.006)$ & $(0.003)$ & $(0.003)$ & $(0.003)$ & $(0.003)$ \\
\hline \multirow[t]{2}{*}{ pi } & $0.103^{* *}$ & $0.110^{* *}$ & $0.105^{* *}$ & $0.127^{* *}$ & $0.047^{* *}$ & $0.050^{* *}$ & $0.047^{* *}$ & $0.059^{* *}$ \\
\hline & $(0.013)$ & (0.013) & $(0.013)$ & (0.013) & $(0.006)$ & $(0.006)$ & $(0.006)$ & $(0.006)$ \\
\hline Likelihood & $-37,399$ & $-36,739$ & $-37,403$ & $-36,009$ & $-37,403$ & $-36,800$ & $-36,268$ & $-36,077$ \\
\hline
\end{tabular}

Notes: ( ) are standard errors.

Dependent Variable=Binary variable, Entering another school within a year after graduation=1. No. of observations $=126,982$.

** : significant at $5 \% / *$ : significant at $10 \%$. 
From these results, it can be seen that socio-economic conditions affect the various aspects of the job market related outcomes of college students. As the previous studies have asserted that institutional variables related to the labor market have statistically significant effect on labor market indicators including unemployment duration, this paper also finds that environmental factors surrounding the labor market affect young workers' job searching behaviors. This implies that analyzing college students' behaviors is also important in understanding the youth labor market since some hidden labor market indicators are observed, which is the integral part of youth employment.

\section{Counterfactual predictions when the labor market situation changes}

Some counterfactual examples should aid better understandings of how the labor market situation will affect college students' job searching related behaviors. Since the change of dependent variables depends on the level of independent variables, some illustrative cases have to be constructed to examine the effect of changes. It is assumed that for a male student, he is age 24, served the military obligation, and majoring in engineering; for a female counterpart, she is age 22, and majoring in sociology. Both cases are presumed to be at a 4 year program school located in Seoul and to have parents' income level from 200 to 400 million won per month.

When the growth rate falls by $1 \% \mathrm{p}$, which is approximately 0.5 sample standard deviation drop, it is calculated that the enrollment period extends by approximately 0.1 semesters. By comparison, when the polarization increases by $1.5 \%$ p, approximately 0.5 sample standard deviation rise, the enrollment period extends by about $0.5 \sim 0.6$ semesters. For the probability of employment and the probability of entering another school, a unit variation in PI seems to show almost 5 times larger effect on those variables than a unit variation in GDP growth rate. The results are provided in Table 8. 


\section{Table 8: Point Estimates of the Changes in the Dependent Variables according to the Labor Market Situation Changes}

\begin{tabular}{|c|c|c|c|c|c|c|}
\hline \multirow{2}{*}{ Situations } & \multicolumn{2}{|c|}{$\begin{array}{l}\text { No. of Semesters } \\
\text { until Graduation }\end{array}$} & \multicolumn{2}{|c|}{$\begin{array}{l}\text { Unemployment } \\
\text { Rate }(\% p)\end{array}$} & \multicolumn{2}{|c|}{$\begin{array}{l}\text { Prob. of Entering } \\
\text { Another School }\end{array}$} \\
\hline & male $^{1)}$ & female ${ }^{2)}$ & male $^{1)}$ & female ${ }^{2)}$ & male $^{1)}$ & female ${ }^{2)}$ \\
\hline $\begin{array}{l}\text { GDP growth rate is } 3.5 \\
\mathrm{PI} \text { increases from } 55 \text { to } 56.5\end{array}$ & 0.546 & 0.61 & 1.587 & 1.487 & 2.446 & 2.871 \\
\hline $\begin{array}{l}\mathrm{PI} \text { is } 55 \text {, and GDP growth } \\
\text { rate decreases from } 4 \text { to } 3\end{array}$ & 0.104 & 0.128 & 0.387 & 0.362 & 0.619 & 0.731 \\
\hline
\end{tabular}

Notes: 1) age 24, military served, 4 year university in Seoul, engineering major, parents' income 200-400. 2) age 22, no military, 4 year university in Seoul, sociology major, parents' income 200-400.

The figure also implies that a unit variation in the unemployment rate is also large when the variation is caused by labor market polarization. For example, if we assume there are 4 year grades in every school, a 1/16 increase in the number of semesters until graduation implies a $1 / 16 \times 25 \%$ increase in students, implying approximately a $1.5 \%$ p increase in college students. Using this logic, if we observe a $1 \%$ p increase in the youth unemployment rate due to a rise in labor market polarization, corresponding increases in college students (1\%p) and the entrance rate of another school after graduation (1.7\%p) altogether constitute a $3.7 \%$ increase in youth unemployment, provided that there is no other way of hiding the unemployment status of students. Likewise, a $1 \% \mathrm{p}$ increase in youth unemployment caused by the sluggish economic growth may imply a $3 \%$ p growth in real unemployment, which is $0.7 \%$ p lower than the one caused by the rise of labor market polarization. To put it simply, a $1 \%$ p increase in college students' unemployment might imply a $2.7 \%$ p or $2 \%$ p increase in the total number of students, depending on what causes the unemployment.

In sum, according to the estimation results, a rise in labor market polarization has a larger effect on youth unemployment than a decline in GDP growth rate, and even greater effect on the job market related behaviors of college students in an effort to hide or evade their unemployment status. 


\section{Conclusion}

It is found that the changes of the labor market situation not only affect youth unemployment but also have significant effects on the hidden behaviors of college students relevant to their job searches. The nominal unemployment rate could be underestimated because of the disguising behaviors of college graduates aiming to avoid putting unemployed period on their resume. Thus, the actual unemployment is hidden by the decision to delay graduation or get into other schools. By looking at the facial value of the youth unemployment rate, the effect of the labor market situation is likely to be undervalued.

Additionally, it is found that the labor market structure, i.e. labor market polarization has significant effects on college students' job market related outcomes. Concerns are usually raised over the relationship between the unemployment rate and the GDP growth rate. However, as employment is a lifetime decision whereas the variation of the GDP growth rate is sometimes cyclical, college students' efforts to make way into the primary labor market should increase when the market segmentation between the primary and the secondary becomes severe. Thus, the structural aspects of the labor market deserve more attention in analyzing the youth labor market.

The policy implication is that in order to lower the youth unemployment, we should focus on macro and institutional level of labor market reform aiming at eliminating the labor market dualism. In other words, the youth labor policy should not only look at the number of job openings, but also focus on institutional barriers hindering labor market mobility and equitable treatment of labors regardless of the position and the industry.

The estimation results imply that in considering the youth labor market, we should look at the graduation duration and the number of college students entering another school after graduation, along with the unemployment rate. In this sense, the youth employment-to-population ratio can be a suitable complement to the youth unemployment rate. Also, the results imply that if a policy aims to reduce youth unemployment, it should focus on the labor market structural reform and concentrate more on the quality of job positions rather than the number of job openings. 
However, there are also some limitations in the analysis regarding causality, endogeneity and representativeness. First, the explanatory variables such as age, type of schools, composition of colleges and majors, and household income level can also be affected by macroeconomic variables, so the estimated significance of macroeconomic variables for the college graduates' behaviors related to the job market could be underestimated. For example, if the labor market is expected to be worse in the future especially in the service sector, it is more probable that students will choose an engineering major than fine arts when entering college, which can reduce the number of semesters enrolled and increase the probability of getting employed after graduation. In this case, the significance of the effect of the labor market can be biased down because of agents' reaction to the anticipated macroeconomic variables.

Secondly, since the analysis is based on micro level data and microeconomic tools, the implications for the change of other macroeconomic variables, caused by labor market changes, are not considered. In reality, macroeconomic variables such as production and consumption should be also adjusted following a large shift of the labor market variable. However, this endogeneity is not considered in the analysis of this paper and left for other macroeconomic analyses. Thus, in interpreting the estimation results provided in this paper, it is not suitable to draw any implications for labor market related outcomes after large structural changes in macroeconomic variables.

Thirdly, considering only contemporary labor market polarization and the GDP growth rate to represent the labor market situation in the analysis might cause bias in the estimation. Since the job market related decision is a long-term one, both the short-term macroeconomic indicators and expected future macroeconomic environment will affect youth labor market related behaviors. If the GDP growth rate and PI do not properly represent all the relevent labor market information that college students encounter, this might produce false implications for the youth labor market. Thus, indepth study on how to find proper variables standing for the labor market is remained for future work. 


\section{References}

Arulampalam, W., and M. B. Stewart (1995), "The Determinants of Individual Unemployment Durations in an Era of High Unemployment," The Economic Journal, Vol. 105, pp. 321-332.

Berg, G. J. V. D., and J. C. V. Ours (1994), "Unemployment Dynamics and Duration Dependence in France, the Netherlands and the United Kingdom," The Economic Journal, Vol. 104, pp. 432-443.

Bulow, J. I., and L. H. Summers (1985), "A Theory of Dual Labor Markets with Application to Industrial Policy, Discrimination, and Keynesian Unemployment,” NBER working Paper, No. 1666, pp. 376-414.

Chung, S., and S. Jung (2016), "Testing the Labor Market Dualism in Korea," BOK Working Paper, No. 13.

Dougherty, C. R. S. (1972), "Substitution and the Structure of the Labour Force," The Economic Journal, pp. 170-182.

Ferguson, B.S. (1986), "Labour Force Substitution and the Effects of an Ageing Population," Applied Economics, Vol. 18, pp. 901-913.

Hamermesh, D. S., and J. H. Grant (1979), "Econometric Studies of Labor-Labor Substitution and their Implications for Policy," Journal of Human Resources, Vol. 14, pp. 518-542.

Isengard, B. (2003), "Youth Unemployment: Individual Risk Factors and Institutional Determinants. A Case Study of Germany and the United Kingdom," Journal of Youth Studies, Vol. 6(4), pp. 357-376.

Jimeno, J. F., and D. Rodriguez-Palenzuela (2002), "Youth Unemployment in the OECD: Demographic Shifts, Labour Market Institutions, and Macroeconomic Shocks," European Central Bank Working Paper Series, No. 155.

Lalive, R., J. C. V. Ours, and J. Zweimüller (2006), "How Changes in Financial Incentives Affect the Duration of Unemployment," Review of Economic Studies, Vol. 73, pp. 1009-1038. 
Lee, H. S. (2010), "Effects of Household Income on Employment of College Graduates," Hanyang Journal of Economic Studies, Vol. 31(2), pp. 47-84.

Lewis, P. E. T. (1985), "Substitution between Young and Adult Workers in Australia," Australian Economic Papers, pp. 115-126.

Merrilees, W. J. (1982), "Labour Market Segmentation in Canada: An Econometric Approach," The Canadian Journal of Economics, Vol. 15(3), pp. 458-473.

Røed, K., and T. Zhang (2003), "Does Unemployment Compensation Affect Unemployment Duration?" The Economic Journal, Vol. 113, pp. 190-260.

Wachter, M. L. (1970), "Cyclical Variation in the Interindustry Wage Structure," The American Economic Review, Vol. 60(1), pp. 75-84. 


\section{$\langle$ Appendix 1$\rangle$}

\section{Estimation of the Effect of Labor Market Polarization on Maintaining Student Status using Year Fixed Effects}

\begin{tabular}{|c|c|c|c|c|c|}
\hline & \multicolumn{2}{|c|}{ Control Variables } & \multicolumn{3}{|c|}{ Year Fixed Effects } \\
\hline & $\begin{array}{c}\text { Hazard } \\
\text { Ratio }\end{array}$ & (s.e.) & & $\begin{array}{c}\text { Hazard } \\
\text { Ratio }\end{array}$ & (s.e.) \\
\hline age & 0.688 & $(0.002)$ ** & 2005 & 1.055 & $(0.031)^{*}$ \\
\hline area & 1.116 & $(0.009) * *$ & 2006 & 0.814 & $(0.027)^{* *}$ \\
\hline school & 3.061 & $(0.026)^{* *}$ & 2007 & 0.868 & $(0.025)^{* *}$ \\
\hline female & 2.766 & $(0.030)^{* *}$ & 2008 & 0.875 & $(0.026)^{* *}$ \\
\hline marriage & 1.107 & $(0.014)^{* *}$ & 2009 & 0.905 & $(0.026)^{* *}$ \\
\hline military & 0.854 & $(0.009)^{* *}$ & 2010 & 0.846 & $(0.025)^{* *}$ \\
\hline major1 & 0.636 & $(0.008)^{* *}$ & 2011 & 0.848 & $(0.025)^{* *}$ \\
\hline major2 & 0.683 & $(0.009)^{* *}$ & 2012 & 0.862 & $(0.026)^{* *}$ \\
\hline major3 & 0.748 & $(0.011)^{* *}$ & 2013 & 1.031 & $(0.031)$ \\
\hline major4 & 0.774 & $(0.013) * *$ & & & \\
\hline major5 & 0.653 & $(0.010)^{* *}$ & & & \\
\hline major6 & 0.720 & $(0.010)^{* *}$ & & & \\
\hline income1 & 1.018 & $(0.009)^{* *}$ & & & \\
\hline income2 & 1.020 & $(0.013)$ & & & \\
\hline income3 & 1.017 & $(0.009)^{* *}$ & & & \\
\hline
\end{tabular}

Notes: Dependent Variable=No. of semesters between college entrance and graduation.

No. of observations $=115,928, * *$ : significant at $5 \% /{ }^{*}$ : significant at $10 \%$.

The table below provides the OLS estimation results using the fitted values of the year fixed effects as dependent variable, and GDP growth rates $(g d p)$ and polarization index $(p i)$ as independent variables. We can check that the polarization index can explain almost $90 \%$ of the year fixed effects. This implies that the market polarization alone can explain much of the duration of student status.

OLS Regression of Year Fixed Effects on GDP growth rate and polarization index

\begin{tabular}{cclcc} 
& coef. & \multicolumn{1}{c}{$($ s.e. } & coef. & (s.e.) \\
gdp & -0.045 & $(0.056)$ & & \\
pi & 1.816 & $(0.431)^{* *}$ & 1.497 & $(0.169)^{* *}$ \\
\hline adj. $R^{2}$ & 0.8805 & & 0.8851 & \\
\hline
\end{tabular}

Note: Dependent Variable=Fitted values of the year fixed effects. 


\section{$\langle$ Appendix 2 $\rangle$}

The tables below provides the robustness check results of the estimation results with the number of months between college graduation and employment, the probability of getting employed, and the probability of entering another school after graduation.

It is found that the estimation results are not robust against the use of alternative proxy variables that stand for the labor market structure and the business cycle phase. Other results are supporting the implications of PI derived from the original estimations.

\section{Robustness Check for the Effect of Labor Market Polarization on the Unemployment Duration}

\begin{tabular}{|c|c|c|c|c|}
\hline & Hazard Ratio & Hazard Ratio & Hazard Ratio & Hazard Ratio \\
\hline & \multicolumn{2}{|c|}{ Alternative Temporal Lags } & \multicolumn{2}{|c|}{ Alternative Data Sets } \\
\hline & (1) & (2) & (3) & (4) \\
\hline \multirow[t]{2}{*}{ gdp } & $1.066^{* *}$ & $1.105^{* *}$ & $0.982^{* *}$ & 1.000 \\
\hline & $(0.005)$ & $(0.008)$ & $(0.005)$ & $(0.010)$ \\
\hline \multirow[t]{4}{*}{ pi } & $1.142^{* *}$ & $1.239^{* *}$ & $1.175^{* *}$ & $1.181^{* *}$ \\
\hline & $(0.013)$ & $(0.016)$ & $(0.012)$ & $(0.027)$ \\
\hline & \multicolumn{2}{|c|}{ Alternative Proxy Variables } & \multicolumn{2}{|c|}{ Alternative Diminishing Rates } \\
\hline & (5) & (6) & (7) & (8) \\
\hline \multirow[t]{2}{*}{ gdp } & $0.920^{* *}$ & $0.913^{* *}$ & $0.987^{* *}$ & $0.984^{* *}$ \\
\hline & $(0.007)$ & (0.009) & $(0.004)$ & $(0.006)$ \\
\hline \multirow[t]{2}{*}{ pi } & 0.985 & $0.921^{* *}$ & $1.161^{* *}$ & $1.187^{* *}$ \\
\hline & $(0.016)$ & $(0.017)$ & $(0.010)$ & $(0.015)$ \\
\hline
\end{tabular}

Notes: ( ) are standard errors.

Dependent Variable=No. of semesters between college graduation and employment.

** : significant at $5 \% / *$ : significant at $10 \%$.

(1) = Variables one year before the year of graduation are used.

(2) = Variables of the average of three years before the year of graduation are used.

(3) = Including the samples entering another school after graduation (sample size=126,982).

(4) = Excluding the samples entering another school, transferred from another school, enrolled in two-year program or enrolled in college outside Seoul (sample size=22,072).

(5) = Using alternative variables, i.e. employment to population ratio and Gini index instead of GDP growth rate and polarization index.

(6) = Using alternative variables one year before the year of graduation.

(7) = Using diminishing rate of $\exp (-0.2)$.

(8) = Using diminishing rate of $\exp (-0.5)$.

Control variables used are the same as in equation (4) of Table 1 except for (4). 


\section{Robustness Check for the Effect of Labor Market Polarization on the Probability of Employment after Graduation}

\begin{tabular}{cccccc} 
& \multicolumn{2}{c}{ Alternative Data Sets } & & \multicolumn{2}{c}{ Alternative Proxy Variables } \\
\cline { 2 - 3 } \cline { 5 - 5 } gdp & (1) logit & (2) probit & & (3) logit & (4) probit \\
pi & 0.009 & 0.005 & & 0.008 & 0.005 \\
& $(0.011)$ & $(0.006)$ & & $(0.007)$ & $(0.004)$ \\
& $-0.092^{* *}$ & $-0.051^{* *}$ & & $0.316^{* *}$ & $0.180^{* *}$ \\
& $(0.025)$ & $(0.014)$ & & $(0.015)$ & $(0.008)$ \\
\hline
\end{tabular}

Notes: ( ) are standard errors.

Dependent Variable=No. of semesters between college graduation and employment.

** : significant at $5 \% /{ }^{*}$ : significant at $10 \%$.

(1) \& (2) = Excluding the samples entering another school, transferred from another school, enrolled in two-year program or enrolled in college outside Seoul (sample size=22,072).

(3) \& (4) = Using alternative variables, i.e. employment to population ratio and Gini index instead of GDP growth rate and polarization index.

\section{Robustness Check for the Effect of Labor Market Polarization on the Probability of Entering Another School after Graduation}

\begin{tabular}{|c|c|c|c|c|}
\hline & \multicolumn{2}{|c|}{ Alternative Data Sets } & \multicolumn{2}{|c|}{ Alternative Proxy Variables } \\
\hline & (1) logit & (2) probit & (3) logit & (4) probit \\
\hline \multirow[t]{2}{*}{ gdp } & $-0.055^{* *}$ & $-0.029^{* *}$ & -0.001 & 0.006 \\
\hline & $(0.013)$ & $(0.007$ & $(0.008)$ & $(0.004)$ \\
\hline \multirow[t]{2}{*}{ pi } & $0.257^{* *}$ & $0.133^{* *}$ & $-0.542^{* *}$ & $-0.275^{* *}$ \\
\hline & $(0.023)$ & $(0.013$ & $(0.019)$ & $(0.010)$ \\
\hline
\end{tabular}

Notes: ( ) are standard errors.

Dependent Variable $=$ No. of semesters between college graduation and employment.

** : significant at $5 \% / *$ : significant at $10 \%$.

(1) \& (2) = Excluding the samples enrolled in two-year program or enrolled in college outside Seoul (sample size $=25,758$ ).

(3) \& (4) = Using alternative variables, i.e. employment to population ratio and Gini index instead of GDP growth rate and polarization index. 


\section{$<$ Abstract in Korean $>$ \\ 노동시장 이중구조가 \\ 대학생의 취업관련 행태에 미치는 영향}

정성엽*

본고에서는 노동시장을 둘러싼 거시경제 변수들이 대학생의 취업관련 행 태에 미치는 영향을 실증분석하였다. 특히 본고에서는 노동시장 양극화가 취 업확률 및 직업탐색기간 등 다양한 변수에 미치는 영향을 종합적으로 추정하 였다. 분석결과 노동시장 양극화는 취업확률은 낮추고 직업탐색기간은 늘리는 것으로 나타났다. 이는 청년실업 관련 정책이 노동시장 이중구조 완화를 위한 미시적·제도적 대책을 중심으로 강화되어야 함을 시사한다.

핵심 주제어: 노동시장, 청년실업, 콕스 비례위험모형

JEL Classification: C25, J13, J21, J64

* 한국은행 조사국 산업고용팀 과장 (전 경제연구원 거시경제연구실 부연구위원)

(전화: 02-759-4291, E-mail: sychung@bok.or.kr)

본 연구내용은 집필자의 개인의견이며 한국은행의 공식견해와는 무관합니다. 따라서 본 논문의 내용을 보도하거나 인용할 경우에는 집필자 명을 반드시 명시하여 주시기 바랍니다. 


\section{$\mathrm{BOK}$ 경제연구 발간목록}

한국은행 경제연구원에서는 Working Paper인 ${ }^{\mathrm{B} B O K}$ 경제연구』를 수시로 발간하고 있습니다. 『BOK 경제연구』는 주요 경제 현상 및 정책 효과에 대한 직관적 설명 뿐 아니라 깊이 있는 이론 또는 실증 분석을 제공함으로써 엄밀한 논증에 초점을 두는 학술논문 형태의 연구이며 한국은행 직원 및 한국은행 연구용역사업의 연구 결과물이 수록되고 있습니다.

${ }^{\circledR} \mathrm{BOK}$ 경제연구』는 한국은행 경제연구원 홈페이지(http://imer.bok.or.kr)에서 다운로드하여 보실 수 있습니다.

제2014-1 Network Indicators for Monitoring Intraday Liquidity in BOK-Wire+

2 중소기업에 대한 신용정책 효과

3 경제충격 효과의 산업간 공행성 분석

4 서비스업 발전을 통한 내외수 균형성장: 기대효과 및 리스크

5 Cross-country-heterogeneous and Time-varying Effects of Unconventional Monetary Policies in AEs on Portfolio Inflows to EMEs

6 인터넷뱅킹, 결제성예금 및 은행 수익성과의 관계 분석

7 Dissecting Foreign Bank Lending Behavior During the 2008-2009 Crisis

8 The Impact of Foreign Banks on Monetary Policy Transmission during the Global Financial Crisis of 2008-2009: Evidence from Korea

9 Welfare Cost of Business Cycles in Economies with Individual Consumption Risk

10 Investor Trading Behavior Around the Time of Geopolitical Risk Events: Evidence from South Korea

11 Imported-Inputs Channel of Exchange Rate Pass-Through: Evidence from Korean Firm-Level Pricing Survey
Seungjin Baek

Kimmo Soram ki . Jaeho Yoon

정호성·임호성

황선웅·민성환 ·

신동현 · 김기호

김승원 · 황광명

Kyoungsoo Yoon •

Christophe Hurlin

이동규·전봉걸

Moon Jung Choi •

Eva Gutierrez •

Maria Soledad Martinez Peria

Bang Nam Jeon •

Hosung Lim. Ji Wu

Martin Ellison •

Thomas J. Sargent

Young Han Kim •

Hosung Jung

Jae Bin Ahn -

Chang-Gui Park 


\begin{tabular}{|c|c|c|}
\hline 제2014-12 & 비대칭 금리기간구조에 대한 실증분석 & 김기호 \\
\hline 13 & $\begin{array}{l}\text { The Effects of Globalization } \\
\text { on Macroeconomic Dynamics } \\
\text { in a Trade-Dependent Economy: } \\
\text { the Case of Korea }\end{array}$ & Fabio Milani $\cdot$ Sung Ho Park \\
\hline 14 & $\begin{array}{l}\text { 국제 포트폴리오투자 행태 분석: 채권-주식 } \\
\text { 투자자금간 상호관계를 중심으로 }\end{array}$ & 이주용·김근영 \\
\hline 15 & $\begin{array}{l}\text { 북한 경제의 추격 성장 가능성과 } \\
\text { 정책 선택 시나리오 }\end{array}$ & 이근 · 최지영 \\
\hline 16 & $\begin{array}{l}\text { Mapping Korea's International Linkages } \\
\text { using Generalised Connectedness Measures }\end{array}$ & Hail Park $\cdot$ Yongcheol Shin \\
\hline 17 & $\begin{array}{l}\text { 국제자본이동 하에서 환율신축성과 } \\
\text { 경상수지 조정: 국가패널 분석 }\end{array}$ & 김근영 \\
\hline 18 & $\begin{array}{l}\text { 외국인 투자자가 외환시장과 주식시장 간 } \\
\text { 유동성 동행화에 미치는 영향 }\end{array}$ & 김준한 $\cdot$ 이지은 \\
\hline 19 & $\begin{array}{l}\text { Forecasting the Term Structure } \\
\text { of Government Bond Yields } \\
\text { Using Credit Spreads and Structural Breaks }\end{array}$ & $\begin{array}{l}\text { Azamat Abdymomunov } \\
\text { Kyu Ho Kang } \\
\text { Ki Jeong Kim }\end{array}$ \\
\hline 20 & $\begin{array}{l}\text { Impact of Demographic Change } \\
\text { upon the Sustainability of Fiscal Policy }\end{array}$ & $\begin{array}{l}\text { Younggak } \mathrm{Kim} \cdot \\
\text { Myoung Chul Kim } \\
\text { Seongyong Im }\end{array}$ \\
\hline 21 & $\begin{array}{l}\text { The Impact of Population Aging } \\
\text { on the Countercyclical Fiscal Stance in Korea, } \\
\text { with a Focus on the Automatic Stabilizer }\end{array}$ & $\begin{array}{l}\text { Tae-Jeong Kim } \cdot \\
\text { Mihye Lee } \cdot \text { Robert Dekle }\end{array}$ \\
\hline 22 & $\begin{array}{l}\text { 미 연준과 유럽중앙은행의 비전통적 통화정책 } \\
\text { 수행원칙에 관한 고찰 }\end{array}$ & 김병기·김진일 \\
\hline 23 & $\begin{array}{l}\text { 우리나라 일반인의 인플레이션 기대 형성 } \\
\text { 행태 분석 }\end{array}$ & 이한규·최진호 \\
\hline
\end{tabular}


제2014-24 Nonlinearity in Nexus between

Working Hours and Productivity

25 Strategies for Reforming Korea's Labor Market to Foster Growth

26 글로벌 금융위기 이후 성장잠재력 확충: 2014 한국은행 국제컨퍼런스 결과보고서

27 인구구조 변화가 경제성장률에 미치는 영향: 자본이동의 역할에 대한 논의를 중심으로

28 Safe Assets

29 확장된 실업지표를 이용한 우리나라 노동시장에서의 이력현상 분석

Entropy of Global Financial Linkages

31 International Currencies Past, Present and Future: Two Views from Economic History

32 금융체제 이행 및 통합 사례:

남북한 금융통합에 대한 시사점

Measuring Price-Level Uncertainty and Instability in the U.S., 1850-2012

고용보호제도가 노동시장 이원화

및 노동생산성에 미치는 영향

35 해외충격시 외화예금의 역할 : 주요 신흥국 신용스프레드에 미치는 영향을 중심으로 Emerging Market Economies, and Their Policy Responses
Dongyeol Lee

Hyunjoon Lim

Mai Dao · Davide Furceri •

Jisoo Hwang

Meeyeon Kim •

Tae-Jeong Kim

한국은행 경제연구원

손종칠

Robert J. Barro

김현학 · 황광명

Daeyup Lee

Barry Eichengreen

김병연

Timothy Cogley •

Thomas J. Sargent

김승원

정호성 - 우준명

김인수 · 이명수

황광명 - 김경민 -

노충식·김미진

Woon Gyu Choi •

Taesu Kang •

Geun-Young Kim •

Byongju Lee 
제2015-1 글로벌 금융위기 이후 주요국

통화정책 운영체계의 변화

2 미국 장기시장금리 변동이 우리나라 금리기간구조에 미치는 영향 분석 및 정책적 시사점

3 직간접 무역연계성을 통한 해외충격의 우리나라 수출입 파급효과 분석

4 통화정책 효과의 지역적 차이

5 수입중간재의 비용효과를 고려한 환율변동과 수출가격 간의 관계

6 중앙은행의 정책금리 발표가 주식시장 유동성에 미치는 영향

7 은행 건전성지표의 변동요인과 거시건전성 규제의 영향

8 Price Discovery and Foreign Participation in The Republic of Korea's Government Bond Futures and Cash Markets

9 규제가 노동생산성에 미치는 영향:

한국의 산업패널 자료를 이용한 실증분석

10 인구 고령화와 정년연장 연구

(세대 간 중첩모형(OLG)을 이용한 정량 분석)

11 예측조합 및 밀도함수에 의한 소비자물가 상승률 전망

12 인플레이션 동학과 통화정책

13 Failure Risk and the Cross-Section of Hedge Fund Returns

14 Global Liquidity and Commodity Prices

15 Foreign Ownership, Legal System and Stock Market Liquidity
김병기·김인수

강규호·오형석

최문정·김근영

김기호

김경민

이지은

강종구

Jaehun Choi - Hosung Lim •

Rogelio Jr. Mercado •

Cyn-Young Park

이동렬· 최종일·이종한

홍재화 - 강태수

김현학

우준명

Jung-Min Kim

Hyunju Kang •

Bok-Keun $\mathrm{Yu}$.

Jongmin $\mathrm{Yu}$

Jieun Lee $\cdot$ Kee H. Chung 
제2015-16 바젤 II 은행 경기대응완충자본 규제의 기준지표에 대한 연구

17 우리나라 대출 수요와 공급의 변동요인 분석

18 북한 인구구조의 변화 추이와 시사점

19 Entry of Non-financial Firms and Competition in the Retail Payments Market

20 Monetary Policy Regime Change and Regional Inflation Dynamics: Looking through the Lens of Sector-Level Data for Korea

21 Costs of Foreign Capital Flows in Emerging Market Economies: Unexpected Economic Growth and Increased Financial Market Volatility

22 글로벌 금리 정상화와 통화정책 과제: 2015년 한국은행 국제컨퍼런스 결과보고서

23 The Effects of Global Liquidity on Global Imbalances

24 실물경기를 고려한 내재 유동성 측정

25 Deflation and Monetary Policy

26 Macroeconomic Shocks and Dynamics of Labor Markets in Korea

27 Reference Rates and Monetary Policy Effectiveness in Korea

28 Energy Efficiency and Firm Growth

29 An Analysis of Trade Patterns in East Asia and the Effects of the Real Exchange Rate Movements

30 Forecasting Financial Stress Indices in Korea: A Factor Model Approach
서현덕·이정연

강종구 · 임호성

최지영

Jooyong Jun

Chi-Young Choi •

Joo Yong Lee

Roisin O'Sullivan

Kyoungsoo Yoon • Jayoung Kim

한국은행 경제연구원

Marie-Louise DJIGBENOU-KRE •

Hail Park

우준명·이지은

Barry Eichengreen

Tae Bong Kim •

Hangyu Lee

Heung Soon Jung •

Dong Jin Lee .

Tae Hyo Gwon .

Se Jin Yun

Bongseok Choi •

Wooyoung Park.

Bok-Keun Yu

Moon Jung Choi •

Geun-Young Kim • Joo Yong Lee

Hyeongwoo Kim • Hyun Hak Kim. Wen Shi 


\begin{tabular}{|c|c|c|}
\hline 제2016 -1 & $\begin{array}{l}\text { The Spillover Effects of U.S. Monetary } \\
\text { Policy on Emerging Market Economies: } \\
\text { Breaks, Asymmetries and } \\
\text { Fundamentals }\end{array}$ & $\begin{array}{l}\text { Geun-Young Kim } \cdot \\
\text { Hail Park· } \\
\text { Peter Tillmann }\end{array}$ \\
\hline 2 & $\begin{array}{l}\text { Pass-Through of Imported Input Prices } \\
\text { to Domestic Producer Prices: Evidence } \\
\text { from Sector-Level Data }\end{array}$ & $\begin{array}{l}\text { JaeBin Ahn } \\
\text { Chang-Gui Park } \\
\text { Chanho Park }\end{array}$ \\
\hline 3 & $\begin{array}{l}\text { Spillovers from U.S. Unconventional } \\
\text { Monetary Policy and Its Normalization } \\
\text { to Emerging Markets: A Capital Flow } \\
\text { Perspective }\end{array}$ & $\begin{array}{l}\text { Sangwon Suh } \\
\text { Byung-Soo Koo }\end{array}$ \\
\hline 4 & $\begin{array}{l}\text { Stock Returns and Mutual Fund Flows } \\
\text { in the Korean Financial Market: } \\
\text { A System Approach }\end{array}$ & $\begin{array}{l}\text { Jaebeom Kim } \\
\text { Jung-Min Kim }\end{array}$ \\
\hline 5 & $\begin{array}{l}\text { 정책금리 변동이 성별·세대별 고용률에 } \\
\text { 미치는 영향 }\end{array}$ & 정성엽 \\
\hline 6 & $\begin{array}{l}\text { From Firm-level Imports to Aggregate } \\
\text { Productivity: Evidence from Korean } \\
\text { Manufacturing Firms Data }\end{array}$ & $\begin{array}{l}\text { JaeBin Ahn } \\
\text { Moon Jung Choi }\end{array}$ \\
\hline 7 & $\begin{array}{l}\text { 자유무역협정(FTA)이 한국 기업의 } \\
\text { 기업내 무역에 미친 효과 }\end{array}$ & 전봉걸·김은숙 $\cdot$ 이주용 \\
\hline 8 & $\begin{array}{l}\text { The Relation Between Monetary and } \\
\text { Macroprudential Policy }\end{array}$ & Jong Ku Kang \\
\hline 9 & $\begin{array}{l}\text { 조세피난처 투자자가 투자 기업 및 주식 } \\
\text { 시장에 미치는 영향 }\end{array}$ & 정호성·김순호 \\
\hline 10 & $\begin{array}{l}\text { 주택실거래 자료를 이용한 주택부문 거시 } \\
\text { 건전성 정책 효과 분석 }\end{array}$ & 정호성·이지은 \\
\hline 11 & $\begin{array}{l}\text { Does Intra-Regional Trade Matter in } \\
\text { Regional Stock Markets?: New } \\
\text { Evidence from Asia-Pacific Region }\end{array}$ & $\begin{array}{l}\text { Sei-Wan Kim } \\
\text { Moon Jung Choi }\end{array}$ \\
\hline 12 & $\begin{array}{l}\text { Liability, Information, and Anti-fraud } \\
\text { Investment in a Layered Retail } \\
\text { Payment Structure }\end{array}$ & $\begin{array}{l}\text { Kyoung-Soo Yoon } \\
\text { Jooyong Jun }\end{array}$ \\
\hline 13 & $\begin{array}{l}\text { Testing the Labor Market Dualism in } \\
\text { Korea }\end{array}$ & $\begin{array}{l}\text { Sungyup Chung. } \\
\text { Sunyoung Jung }\end{array}$ \\
\hline 14 & $\begin{array}{l}\text { 북한 이중경제 사회계정행렬 추정을 통한 } \\
\text { 비공식부문 분석 }\end{array}$ & 최지영 \\
\hline
\end{tabular}




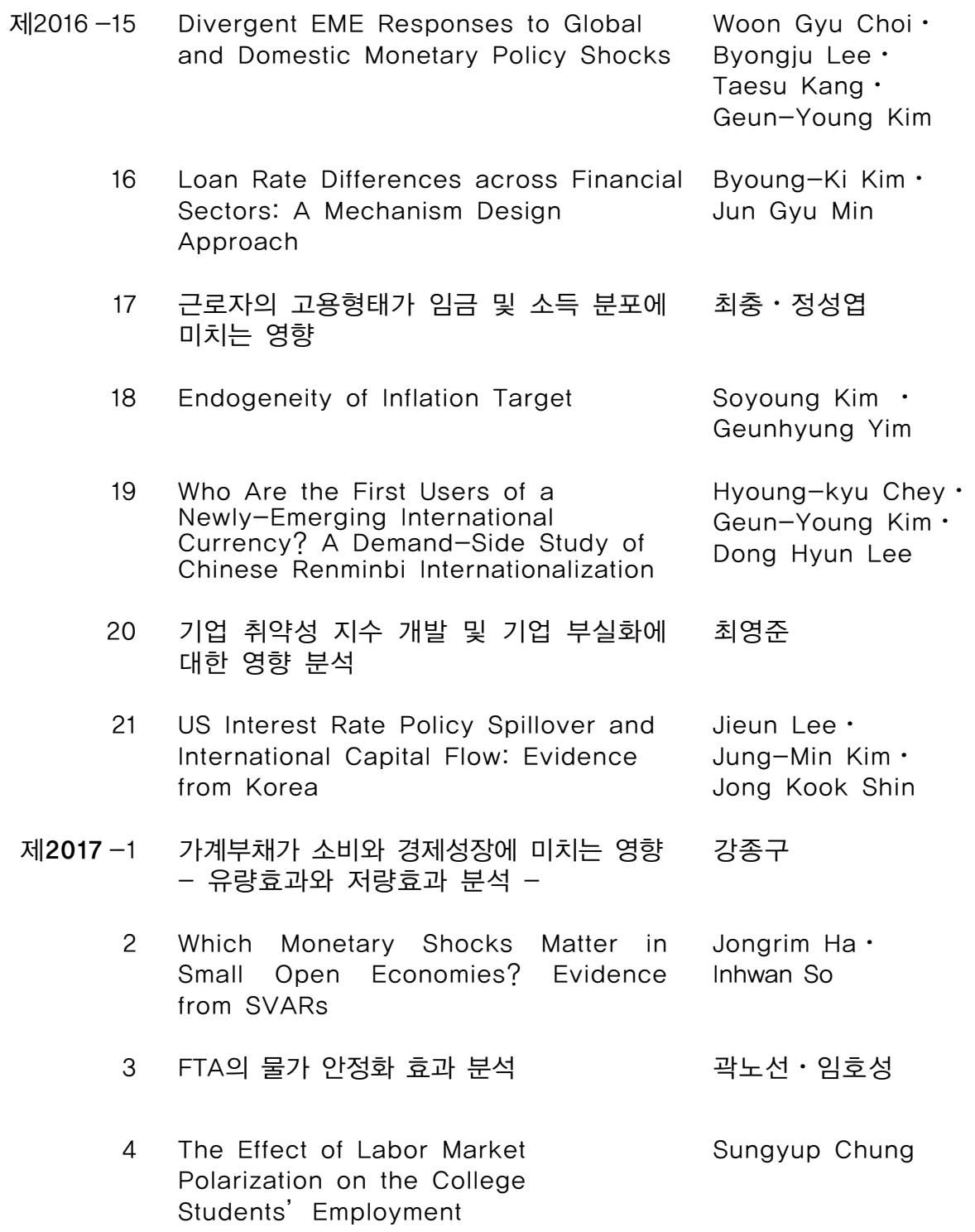

20 기업 취약성 지수 개발 및 기업 부실화에 최영준 대한 영향 분석

21 US Interest Rate Policy Spillover and International Capital Flow: Evidence from Korea

Jieun Lee Jung-Min Kim • Jong Kook Shin

제2017-1 가계부채가 소비와 경제성장에 미치는 영향 강종구 - 유량효과와 저량효과 분석 -

2 Which Monetary Shocks Matter in Jongrim Ha. Small Open Economies? Evidence Inhwan So from SVARs

$3 \mathrm{FTA}$ 의 물가 안정화 효과 분석 곽노선 - 임호성

4 The Effect of Labor Market Polarization on the College Sungyup Chung Students' Employment 